\title{
Aphanizomenon gracile (Nostocales), a cylindrospermopsin- producing cyanobacterium in Polish lakes
}

\author{
Mikołaj Kokociński • Joanna Mankiewicz-Boczek • \\ Tomasz Jurczak • Lisa Spoof • Jussi Meriluoto • \\ Edyta Rejmonczyk • Henna Hautala • \\ Markus Vehniäinen • Jakub Pawełczyk • Janne Soininen
}

Received: 6 September 2012 / Accepted: 11 December 2012 /Published online: 2 February 2013

(C) The Author(s) 2013. This article is published with open access at Springerlink.com

\begin{abstract}
The cyanobacterial cytotoxin cylindrospermopsin (CYN) has become increasingly common in fresh waters worldwide. It was originally isolated from Cylindrospermopsis raciborskii in Australia; however, in European waters, its occurrence is associated with other cyanobacterial species belonging to the genera Aphanizomenon and Anabaena. Moreover, cylindrospermopsin-producing strains of widely distributed $C$. raciborskii have not yet been observed in European waters. The aims of this work were to assess the occurrence of CYN in lakes of western Poland and to identify the CYN producers. The ELISA tests, high-performance liquid chromatography (HPLC)-DAD, and HPLC-mass spectrometry (MS)/MS were conducted to assess the occurrence of CYN in 36 lakes. The cyrJ, cyrA, and pks genes were amplified to identify
\end{abstract}

Responsible editor: Robert Duran

M. Kokociński $(\bowtie)$

Collegium Polonicum, Adam Mickiewicz University,

Kościuszki 1,

69-100 Słubice, Poland

e-mail: kok@amu.edu.pl

M. Kokociński

Department of Hydrobiology, Faculty of Biology,

Adam Mickiewicz University, Umultowska 89,

61-614 Poznań, Poland

J. Mankiewicz-Boczek • E. Rejmonczyk

European Regional Centre of Ecohydrology u/a UNESCO

of the Polish Academy of Sciences, Tylna 3,

90-364 Łódź, Poland

T. Jurczak

Department of Applied Ecology, University of Łódź,

Banacha 12/16,

90-237 Łódź, Poland toxigenic genotypes of cyanobacteria that are capable of producing CYN. The toxicity and toxigenicity of the C. raciborskii and Aphanizomenon gracile strains isolated from the studied lakes were examined. Overall, CYN was detected in 13 lakes using HPLC$\mathrm{MS} / \mathrm{MS}$, and its concentrations varied from trace levels to $3.0 \mu \mathrm{gL}^{-1}$. CYN was widely observed in lakes of western Poland during the whole summer under different environmental conditions. Mineral forms of nutrients and temperature were related to CYN production. The molecular studies confirmed the presence of toxigenic cyanobacterial populations in all of the samples where CYN was detected. The toxicity and toxigenicity analyses of isolated cyanobacteria strains revealed that $A$. gracile was the major producer of CYN.

L. Spoof $\cdot$ J. Meriluoto

Department of Biosciences, Biochemistry,

Åbo Akademi University, Tykistökatu 6A,

20520 Turku, Finland

H. Hautala $\cdot$ M. Vehniäinen

Department of Biotechnology, University of Turku,

Tykistökatu 6A,

20520 Turku, Finland

J. Pawełczyk

Institute for Medical Biology of the Polish

Academy of Sciences, Lodowa 106,

93-232 Łódź, Poland

J. Soininen

Department of Geosciences and Geography,

University of Helsinki, PO Box 64, 00014 Helsinki, Finland 
Keywords Aphanizomenon gracile · Cylindrospermopsis raciborskii - Cyanotoxins - Cylindrospermopsin $\cdot$ cyrA . $c y r \mathrm{~J} \cdot p k s \cdot$ Toxicity $\cdot$ Lakes

\section{Introduction}

The occurrence of cylindrospermopsin (CYN) is of major concern for both drinking water supplies and recreational water use because it can affect the health of wildlife and humans (Carmichael and Falconer 1993). CYN is a potent hepatotoxic alkaloid consisting of a tricyclic guanidine moiety combined with hydroxymethyluracil that inhibits protein synthesis and causes pathological symptoms in the liver, spleen, thymus, kidney, and heart (Terao et al. 1994; Hawkins et al. 1997; Falconer et al. 1999; Froscio et al. 2003; van Apeldoorn et al. 2007). Further studies have revealed CYN to be genotoxic, causing DNA strand breakage (Humpage et al. 2000; Shen et al. 2002) and DNA damage in non-liver cells (Žegura et al. 2011). Moreover, mutagenic and carcinogenic effects of CYN have also been demonstrated (Humpage et al. 2000; Falconer and Humpage 2001; Bazin et al. 2010). Recent studies have revealed the environmental toxicity of CYN towards different groups of organisms, including amphibians (Kinnear et al. 2007), gastropods (White et al. 2006), fish (Gutiérrez-Praena et al. 2012), plants (Metcalf et al. 2004), and aquatic macrophytes (Kinnear et al. 2008), as well as antibacterial activity (Rasmussen et al. 2008). Two other structural variants of CYN have been isolated: deoxy-cylindrospermopsin (Norris et al. 1999) and 7-epicylindrospermopsin (Banker et al. 2000).

CYN was first isolated from Cylindrospermopsis raciborskii (Ohtani et al. 1992), which was detected in drinking water supply reservoirs on Palm Island, Australia, where an outbreak of hepatoenteritis occurred among the aboriginal community (Bourke et al. 1983). Previously, this common bloomforming cyanobacterium native to the Australian waters was the only known CYN-producing species. In addition to Australia, CYN-producing strains of $C$. raciborskii have now also been isolated in New Zealand (Wood and Stirling 2003), Japan (Chonudomkul et al. 2004; Zarenezhad et al. 2012), and Thailand (Li et al. 2001a). Currently, CYN has been detected worldwide and is known to be produced by a number of cyanobacteria, including Umezakia natans in Japan (Harada et al. 1994); Aphanizomenon ovalisporum, e.g., in Israel, Australia, Spain, and Italy (Banker et al. 1997; Shaw et al. 1999; Quesada et al. 2006; Messineo et al. 2010); Raphidiopsis curvata in China (Li et al. 2001b) and Anabaena bergii, Lyngbya wollei, and Raphidiopsis mediterranea in Australia (Schembri et al. 2001; Seifert et al. 2007; McGregor et al. 2011). In Europe, two additional CYNproducing species were found: Aphanizomenon flos-aquae in Germany (Preußel et al. 2006) and Anabaena lapponica in Finland (Spoof et al. 2006). Moreover, recent studies by
Wiedner et al. (2008) indicated Aphanizomenon gracile to be a potential producer of this toxin in German waters. Aside from Germany, Spain, Finland and Italy, CYN was also detected in other localities in Europe, including Portugal (Saker et al. 2003), France (Brient et al. 2009), and the Czech Republic (Bláhová et al. 2009), where Anabaena planctonica and A. flos-aquae var. klebahnii have been reported as potential producers of CYN (Brient et al. 2009; Bláhová et al. 2009). Therefore, it is likely that CYN is widely distributed in European waters; however, the list of potential producers of this toxin remains incomplete. Moreover, no CYN-producing strains of $C$. raciborskii have yet been isolated, although it is a commonly occurring species in this region (Fastner et al. 2003, 2007; Saker et al. 2003; Bernard et al. 2003; Haande et al. 2008; Antal et al. 2011; MankiewiczBoczek et al. 2012). In Poland, CYN was first detected in 2006 in two shallow eutrophic lakes (Kokociński et al. 2009), and preliminary molecular identification has shown that Aphanizomenon sp. appears to be the primary cyanobacterial genus responsible for the production of CYN in Polish lakes (Mankiewicz-Boczek et al. 2012). Our recent study showed that $C$. raciborskii and Aphanizomenon spp. were common in eutrophic lakes in western Poland Kokociński and Soininen (2012). These lakes are very often used for recreation during the summer season or they supply water to agriculture farms. However, the knowledge about toxin concentration in these waters is very limited. Since the CYN concentrations detected in the earlier investigation (Kokocinski et al. 2009) exceeded the guideline value recommended by Humpage and Falconer (2003), further studies on the distribution of CYN and its producers are needed.

Therefore, the objectives of this study were (1) to assess the occurrence and distribution of CYN in Polish lakes and (2) to identify the cyanobacteria species capable of producing CYN.

\section{Materials and methods}

\section{Study site}

The study was conducted in 36 randomly selected lakes in western Poland (Fig. 1). The lakes varied in morphometry (e.g., maximum depth, volume, and surface area), mixing regime (i.e., dimictic, and polymictic), and trophic status. The limnological characteristics and geographical positions of the lakes are presented in Table 1.

\section{Sampling}

The lakes were sampled twice in 2010, with the first sampling period taking place from 6 June to 23 July (the "beginning of summer") and the second from 20 August to 1 October (the "end of summer"). Integrated phytoplankton samples were 
Fig. 1 Study area with the distribution of cylindrospermopsin (black circles indicate lakes with cylindrospermopsin)

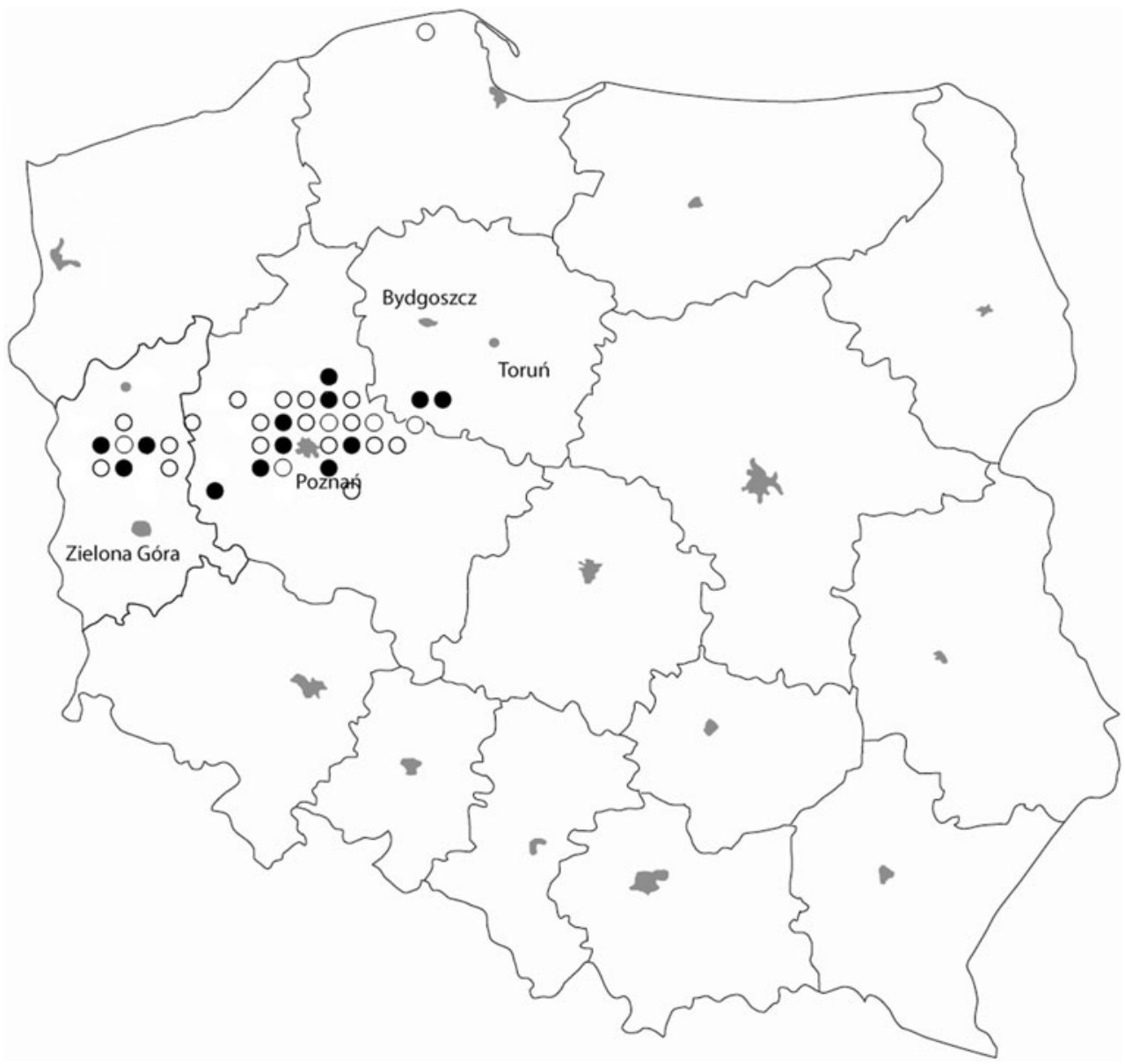

collected from one sampling station in the middle of each lake, from the water column in polymictic lakes or from the epilimnion in stratified lakes, using a 0.5 -m-long "Limnos" sampler. In both cases, subsamples were taken from every $1 \mathrm{~m}$ of a vertical profile, pooled in a plastic bucket and then mixed. The number of subsamples depended on the maximum depth of the shallow lakes (from 1 to $3 \mathrm{~m}$ ) and on the depth of the epilimnion in the stratified lakes (from 1 to $4 \mathrm{~m}$ ). Following the initial collection, pooling, and mixing of the samples, subsamples measuring $1 \mathrm{~L}$ in volume were collected and transported to the laboratory for the phytoplankton and chemical analyses.

\section{Phytoplankton analysis}

The phytoplankton samples were preserved with acid Lugol's solution with a final concentration of 1 \% (APHA 1998; Hötzel and Croome 1999; Hawkins et al. 2005) immediately after sampling and were stored in cool and dark conditions. The phytoplankton samples were then analyzed within the next few weeks. Before counting the plankton, the samples were left undisturbed for at least $48 \mathrm{~h}$ in glass cylinders. The upper layer of the water was then gently decanted and the lower layer $(40 \mathrm{~mL})$ containing the settled plankton species was used for the analysis.
The phytoplankton were morphologically identified with reference to Starmach (1989); Komárek and Anagnostidis (1989, 1998); Hindak (2000); Komárek and Komárkova (2003, 2004); Komárek and Anagnostidis (2005); Komárek and Komárkova (2006); Komárek and Zapomělová (2007, 2008); Komárek (2010). Identification of isolated strains of A. gracile was additionally verified by consulting with Prof. Hindak. The phytoplanktons were counted using a FuchsRosenthal chamber (Brand $\mathrm{GmbH}+\mathrm{CO} \mathrm{KG}, \mathrm{PO}$ Box 1155 97861 Wertheim, Germany). At least 400 specimens were counted to reduce the error to $<10 \%(p=0.05$; Javornick 1958). A single cell, a cenobium, or a filament represented one specimen in the analyses. Phytoplankton identification and counts were conducted using Carl Zeiss (Axioskop 2 Mot, Germany) light microscope under $\times 400$ magnification. The biovolume of each species was determined through the volumetric analysis of cells using a geometric approximation and was expressed as wet weight following the guidelines of Hindak (1978) and Wetzel and Likens (2000).

\section{Cyanobacteria cultures}

The $A$. gracile and $C$. raciborskii strains were isolated under Carl Zeiss light microscope (magnification $\times 400$ ) from the 
Table 1 Geographical position and morphometric parameters of investigated lakes

\begin{tabular}{|c|c|c|c|c|c|c|}
\hline Lake & Latitude & Longitude & Lake surface [ha] & Mean depth $[\mathrm{m}]$ & Max. depth [m] & Lake volume $\left[\times 1,000 \mathrm{~m}^{3}\right]$ \\
\hline Głębokie (P) & $52^{\circ} 33^{\prime} 41^{\prime \prime}$ & $17^{\circ} 20^{\prime} 33^{\prime \prime}$ & 20.0 & 3.3 & 6.0 & 833.2 \\
\hline Ilno (P) & $52^{\circ} 18^{\prime} 31^{\prime \prime}$ & $15^{\circ} 04^{\prime} 42^{\prime \prime}$ & 12.3 & 2.4 & 4.9 & 295.2 \\
\hline Kursko (S) & $52^{\circ} 45^{\prime} 45 \mathrm{I}$ & $15^{\circ} 45^{\prime} 26^{\prime \prime}$ & 75.0 & 4.3 & 8.5 & $3,038.5$ \\
\hline Biskupieckie (P) & $52^{\circ} 23^{\prime} 16 \ddot{I}$ & $14^{\circ} 40^{\prime} 00^{\prime \prime}$ & 10.0 & 1.5 & 2.7 & 187.9 \\
\hline Lusowskie (S) & $52^{\circ} 25^{\prime} 50^{\prime \prime}$ & $16^{\circ} 40^{\prime} 20^{\prime \prime}$ & 121.9 & 8.6 & 19.5 & $10,479.0$ \\
\hline Strykowskie (S) & $52^{\circ} 15^{\prime} 26^{\prime \prime}$ & $16^{\circ} 36^{\prime} 34^{\prime \prime}$ & 297.5 & 4.5 & 7.7 & $13,637.4$ \\
\hline Długie (P) & $52^{\circ} 28^{\prime} 11^{\prime \prime}$ & $15^{\circ} 27^{\prime} 05^{\prime \prime}$ & 8.5 & 3.3 & 4.5 & 453.5 \\
\hline Kierskie (S) & $52^{\circ} 27^{\prime} 10^{\prime \prime}$ & $16^{\circ} 47^{\prime} 35^{\prime \prime}$ & 285.0 & 11.0 & 34.1 & $34,100.0$ \\
\hline Kierskie Małe (P) & $52^{\circ} 29^{\prime} 12^{\prime \prime}$ & $16^{\circ} 47^{\prime} 14^{\prime \prime}$ & 26.0 & 1.4 & 2.3 & 476.0 \\
\hline Żabiniec $(\mathrm{P})$ & $52^{\circ} 30^{\prime} 14^{\prime \prime}$ & $14^{\circ} 43^{\prime} 31^{\prime \prime}$ & 35.5 & 2.0 & 4.0 & $1,023.2$ \\
\hline Busko (P) & $52^{\circ} 22^{\prime} 58^{\prime \prime}$ & $14^{\circ} 50^{\prime} 57^{\prime \prime}$ & 46.7 & 1.6 & 3.6 & 513.7 \\
\hline Lubosińskie (P) & $52^{\circ} 31^{\prime} 40^{\prime \prime}$ & $16^{\circ} 22^{\prime} 57^{\prime \prime}$ & 23.8 & 2.6 & 3.7 & 627.3 \\
\hline Biezdruchowo (S) & $52^{\circ} 29^{\prime} 15^{\prime \prime}$ & $17^{\circ} 16^{\prime} 40^{\prime \prime}$ & 37.5 & 5.7 & 17.7 & $2,815.5$ \\
\hline Pniewskie (P) & $52^{\circ} 30^{\prime} 41^{\prime \prime}$ & $16^{\circ} 14^{\prime} 27^{\prime \prime}$ & 55.0 & 1.5 & 3.3 & 898.7 \\
\hline Grylewskie (P) & $52^{\circ} 53^{\prime} 07^{\prime \prime}$ & $17^{\circ} 15^{\prime} 04^{\prime \prime}$ & 98.0 & 3.6 & 6.5 & $4,329.0$ \\
\hline Zbąszyńskie (P) & $52^{\circ} 14^{\prime} 05^{\prime \prime}$ & $15^{\circ} 54^{\prime} 13^{\prime \prime}$ & 742.5 & 3.5 & 9.6 & $26,178.7$ \\
\hline Świętokrzyskie (P) & $52^{\circ} 32^{\prime} 39^{\prime \prime}$ & $17^{\circ} 35^{\prime} 43^{\prime \prime}$ & 11.0 & 2.9 & 6.3 & 420.0 \\
\hline Kowalskie (P) & $52^{\circ} 28^{\prime} 37^{\prime \prime}$ & $17^{\circ} 10^{\prime} 20^{\prime \prime}$ & 203.0 & 4.0 & 7.0 & $7,589.5$ \\
\hline Szydłowskie (S) & $52^{\circ} 35^{\prime} 02^{\prime \prime}$ & $17^{\circ} 55^{\prime} 52^{\prime \prime}$ & 128.5 & 11.3 & 24.5 & $15,883.9$ \\
\hline Raczyńskie (P) & $52^{\circ} 08^{\prime} 36^{\prime \prime}$ & $17^{\circ} 09^{\prime} 56^{\prime \prime}$ & 93.5 & 2.7 & 5.8 & $2,342.9$ \\
\hline Lednica (S) & $52^{\circ} 31^{\prime} 51^{\prime \prime}$ & $17^{\circ} 22^{\prime} 30^{\prime \prime}$ & 325.0 & 7.0 & 15.1 & $24,397.0$ \\
\hline Buszewskie (S) & $52^{\circ} 32^{\prime} 34^{\prime \prime}$ & $16^{\circ} 22^{\prime} 38^{\prime \prime}$ & 79.8 & 4.8 & 14.0 & $3,810.7$ \\
\hline Niepruszewskie (P) & $52^{\circ} 22^{\prime} 45^{\prime \prime}$ & $16^{\circ} 36^{\prime} 56^{\prime \prime}$ & 227.5 & 3.1 & 5.2 & $7,578.3$ \\
\hline Tomickie $(\mathrm{P})$ & $52^{\circ} 19^{\prime} 02^{\prime \prime}$ & $16^{\circ} 38^{\prime} 06^{\prime \prime}$ & 47.2 & 1.8 & 2.7 & 786.7 \\
\hline Jelonek $(\mathrm{P})$ & $52^{\circ} 32^{\prime} 04^{\prime \prime}$ & $17^{\circ} 35^{\prime} 17^{\prime \prime}$ & 9.5 & 1.2 & 2.4 & 172.8 \\
\hline Mogileńskie (P) & $52^{\circ} 38^{\prime} 33^{\prime \prime}$ & $17^{\circ} 57^{\prime} 11^{\prime \prime}$ & 72.5 & 3.2 & 6.8 & $2,526.5$ \\
\hline Witobelskie (P) & $52^{\circ} 15^{\prime} 55^{\prime \prime}$ & $16^{\circ} 43^{\prime} 32^{\prime \prime}$ & 100.3 & 1.7 & 3.7 & $5,579.0$ \\
\hline Boczowskie (P) & $52^{\circ} 19^{\prime} 10^{\prime \prime}$ & $14^{\circ} 56^{\prime} 47^{\prime \prime}$ & 13.5 & 1.6 & 3.7 & 578.9 \\
\hline Bnińskie (P) & $52^{\circ} 12^{\prime} 02^{\prime \prime}$ & $17^{\circ} 06^{\prime} 59^{\prime \prime}$ & 221.5 & 4.0 & 8.5 & $9,525.6$ \\
\hline Bytyńskie (P) & $52^{\circ} 29^{\prime} 55^{\prime \prime}$ & $16^{\circ} 30^{\prime} 30^{\prime \prime}$ & 308.8 & 3.5 & 7.0 & $11,837.5$ \\
\hline Niesłysz (S) & $52^{\circ} 14^{\prime} 07^{\prime \prime}$ & $15^{\circ} 23^{\prime} 02^{\prime \prime}$ & 486.5 & 7.1 & 35 & $34,457.6$ \\
\hline Sarbsko (P) & $54^{\circ} 45^{\prime} 23^{\prime \prime}$ & $17^{\circ} 35^{\prime} 26^{\prime \prime}$ & 650 & 1.4 & 3.5 & $10,612.7$ \\
\hline Biskupińskie (S) & $52^{\circ} 47^{\prime} 41^{\prime \prime}$ & $17^{\circ} 44^{\prime} 56^{\prime \prime}$ & 107.1 & 5.5 & 13.7 & $6,397.2$ \\
\hline Lubieckie (S) & $52^{\circ} 41^{\prime} 11^{\prime \prime}$ & $17^{\circ} 40^{\prime} 49^{\prime \prime}$ & 47.7 & 4.9 & 8.6 & $2,351.1$ \\
\hline Kruchowskie (P) & $52^{\circ} 36^{\prime} 13^{\prime \prime}$ & $17^{\circ} 48^{\prime} 22^{\prime \prime}$ & 35.0 & 1.5 & 2.9 & 522.9 \\
\hline Strzyżewskie (S) & $52^{\circ} 34^{\prime} 14^{\prime \prime}$ & $17^{\circ} 39^{\prime} 34^{\prime \prime}$ & 49.9 & 5.8 & 13.3 & $2,890.6$ \\
\hline
\end{tabular}

$P$ polymictic, $S$ stratified

environmental samples. Single filaments of these species were collected using a Pasteur's glass pipette and transferred to culture flasks containing sterile BG-11 media. This procedure was repeated until monocultures of the cyanobacteria were obtained. All together, 11 strains of $A$. gracile and six strains of $C$. raciborskii were isolated. Each strain was isolated from a different lake. The isolates were incubated in $250 \mathrm{~mL}$ Erlenmeyer flasks containing $150 \mathrm{~mL}$ medium in an incubation chamber (Poleko Sp.j., Wodzisław Śl., Poland) at $21^{\circ} \mathrm{C}$ under $80 \mu \mathrm{mol}$ photon per square meter per second irradiance using cool white fluorescent light with a photoperiod regime of $12 \mathrm{~h}$ dark and $12 \mathrm{~h}$ light. The culture material was harvested at the beginning of the stationary growth phase for toxin analysis. From each strain, $100 \mathrm{~mL}$ for enzyme-linked immunosorbent assay (ELISA) and high-performance liquid chromatography (HPLC) analysis and $10 \mathrm{~mL}$ for molecular analysis of culture material was filtered through a sterile GF/ $\mathrm{C}$ Whatman filter. The strains are maintained in the culture collection in the Department of Hydrobiology at Adam Mickiewicz University. 
Cultures of Anabaena lapponica 966 (obtained from Finnish Environment Institute, Helsinki, Finland; Spoof et al. 2006) and C. raciborskii CSIRO 506 and 505 (CSIRO Collection of Living Microalgae, Hobart, Australia) were maintained at Åbo Akademi University and utilized in the evaluation of the analytical performance and in PCR work ("HPLC analysis" section and "Quantitative analysis of the cyrA gene" section, respectively).

\section{Chemical and physical analyses}

The integrated water samples were analyzed for ammonium $\left(\mathrm{NH}_{4}{ }^{+}\right)$levels using a manual spectrometric method (PNISO 7150-1:2002). Nitrate $\left(\mathrm{NO}_{3}{ }^{-}\right)$and nitrite $\left(\mathrm{NO}_{2}{ }^{-}\right)$levels were analyzed by determining the concentration of dissolved anions using liquid chromatography (ISO 103041:2007). The total nitrogen was calculated according to (PN-73/C-04576/14: 1973). $\mathrm{PO}_{4}{ }^{3-}$ and total phosphorus were determined using the ammonium molybdate spectrometric method (ISO 6878: 2004).

For the chlorophyll $a$ (chl-a) analysis, $200 \mathrm{~mL}$ of water was filtered through a GF/C Whatman filter. The concentration was then determined spectrophotometrically after $90 \%$ acetone extraction and calculated using Lorenzen's formula (Wetzel and Likens 2000). For each sample, the Secchi depth, water temperature, $\mathrm{pH}$, and conductivity were determined in situ using a multiparameter probe (Elmetron CPC401, Elmetron Sp.j. Zabrze, Poland).

\section{Cylindrospermopsin analysis}

\section{ELISA tests}

First, an ELISA was carried out to detect the particulate and dissolved CYN concentrations in both the environmental and the culture samples. To determine the dissolved CYN concentration before analysis, $200 \mathrm{~mL}$ samples were filtered immediately after sampling through GF/C (Whatman, UK) filters. The filtered water was then used for analysis. To detect the total CYN concentration, raw unfiltered water samples were sonicated for $2 \mathrm{~min}$ in an ice bath with a 60 s pause. The $250 \mu \mathrm{L}$ sonicated suspensions and filtered water samples were centrifuged at $12,000 \times \mathrm{g}$ for $10 \mathrm{~min}$. Direct competitive ELISA tests based on polyclonal antibodies were conducted following the manufacturer's instructions (Abraxis LLC, USA). The absorbance was measured at $450 \mathrm{~nm}$ using a spectrophotometer (BioTek Instruments, Inc., Winooski, VT, USA). The detection limit for this assay was $0.04 \mu \mathrm{gL}^{-1}$. The particulate CYN concentration in the investigated samples was calculated by subtracting the dissolved CYN concentration from the total concentration of CYN.

\section{HPLC analysis}

Sample preparation The sample preparation method was based on results from an international interlaboratory exercise on cylindrospermopsin measurement (Törökné et al. 2004) but developed further in our laboratory (Spoof et al. 2006). These investigations showed that cell-bound CYN was successfully extractable from freeze-dried cyanobacterial cells by either aqueous or methanolic solvents. Extraction by acidified methanol resulted in clear HPLCdiode array UV detection (DAD) chromatograms with low amounts of co-extracted compounds eluting in the vicinity of CYN (Spoof et al. 2006).

The analysis of lake water samples for CYN was conducted in the following manner: $200 \mathrm{~mL}$ water samples were filtered on a $47 \mathrm{~mm}$ diameter $\mathrm{GF} / \mathrm{C}$ Whatman filter, freeze-dried and stored at $-20{ }^{\circ} \mathrm{C}$ until the CYN analysis. The filter was cut with a scalpel in two halves. One half of the filter was extracted with $1.2 \mathrm{~mL}$ of methanol containing $0.1 \%$ trifluoroacetic acid (TFA) (protein sequence analysis grade; Fluka, Buchs, Switzerland) in a bath sonicator (Bandelin Sonorex RK 156, Berlin, Germany) for $15 \mathrm{~min}$. The samples were further treated with a probe sonicator (Bandelin Sonopuls HD 2070 with a $3 \mathrm{~mm}$ microtip, $30 \%$ pulse, $30 \%$ energy) for $1 \mathrm{~min}$ on ice. The extracts were then centrifuged at $10,000 \times \mathrm{g}$ for $10 \mathrm{~min}$, and $600 \mu \mathrm{L}$ of the supernatant was evaporated with argon at $40{ }^{\circ} \mathrm{C}$ (the remaining supernatant was kept for possible further analyses). The dry residue was resuspended in $200 \mu \mathrm{L}$ of water and clarified by centrifugation before analysis by HPLC-DAD and HPLC-mass spectrometry (MS)/MS.

Appropriate quality assurance as described below consisted of the following assessments: (a) the stability of CYN during the extraction procedure, (b) the efficiency of the extraction procedure, (c) the precision of the complete analytical procedure, and (d) the repeatability of the complete analytical procedure. Addressing the points (a) and (b) contributed to the accuracy of the analysis. The accuracy was further improved by using a Certified Reference Material of CYN. The quality assurance was complemented by calculation of chromatographic parameters and detection limits.

(a) The stability of CYN during the extraction procedure was verified in the following manner. Samples of $4 \mu \mathrm{g}$ CYN in replicate were dissolved in $1.2 \mathrm{~mL}$ of extraction solvent, methanol containing $0.1 \%$ TFA. A 200 $\mu \mathrm{L}$ sample was taken aside, evaporated to dryness, redissolved in $200 \mu \mathrm{L}$ water, and analyzed for CYN by HPLC-DAD as detailed below. The remaining $1,000 \mu \mathrm{L}$ sample was subjected to bath and probe sonication, evaporated to dryness, and redissolved in $1,000 \mu \mathrm{L}$ methanol containing $0.1 \%$ TFA. A $200 \mu \mathrm{L}$ sample was again taken aside, evaporated to dryness, 
redissolved in $200 \mu \mathrm{L}$ water, and analyzed for CYN. The remaining $800 \mu \mathrm{L}$ sample was subjected to bath and probe sonication, evaporated to dryness, redissolved in $800 \mu \mathrm{L}$ water, and analyzed for CYN. The results are reported in Table 2.

(b) The efficiency of the extraction procedure was verified by sequential extraction of cyanobacterial samples derived from a culture of Anabaena lapponica 966. The samples to be extracted were prepared in the following manner: $100 \mathrm{~mL}$ samples of the culture were filtered on $47 \mathrm{~mm}$ diameter $\mathrm{GF} / \mathrm{C}$ Whatman filters $(n=5)$ and freeze-dried. The filters were cut in two halves. One of the halves of each filter was extracted with $1.2 \mathrm{~mL}$ of methanol containing $0.1 \%$ TFA using the bath and probe sonication procedure as described above. Seven hundred microliters were taken aside, clarified by centrifugation, and a part of the supernatant was concentrated threefold by evaporation and redissolving in water. This aqueous sample from the first extraction round was then analyzed for CYN by HPLC-DAD and HPLC-MS/MS. Seven hundred microliters of extraction solvent was added onto the remaining wet filter material (making up the total volume to $1.2 \mathrm{~mL}$ ), and the probe sonication was repeated. Seven hundred microliters was again taken aside, clarified by centrifugation, and a part of the supernatant was concentrated threefold by evaporation and redissolving in water. The aqueous sample from the second extraction round was then analyzed for CYN. Seven hundred microliters of extraction solvent was again added onto the remaining wet filter material (making up the total volume to $1.2 \mathrm{~mL}$ ), and the probe sonication was repeated for the third time. The extract was clarified by centrifugation, and a part of the supernatant was concentrated threefold by evaporation and redissolving in water. The aqueous sample from the third extraction round was then analyzed for CYN. The results are reported in Table 3.

(c) The precision of the complete analytical method was assessed by analyzing the CYN content in cultured samples of Anabaena lapponica 966 and C. raciborskii CSIRO 506. Two different densities of the cultures, here called full strength and dilute, were used for the assessment. Two hundred-milliliter samples $(n=5)$ were filtered on $47-\mathrm{mm} \mathrm{GF} / \mathrm{C}$ filters, freeze-dried, cut in halves, extracted as described above, and analyzed by HPLC-DAD and HPLC-MS/MS. As it was impossible to pass $200 \mathrm{~mL}$ of the full-strength Anabaena 966 culture through the GF/C filter, only $100-\mathrm{mL}$ samples were filtered in this case.

(d) The repeatability of the complete analytical method, i.e., variation in analysis performed by a single person on replicate samples and under the same conditions, was assessed by extracting and analyzing a set of half filters on two different days. The results are reported in Table 4.

Cylindrospermopsin analysis by HPLC-diode-array UV detection The chromatographic separation was performed using an Agilent (Waldbronn, Germany) 1100 series HPLC system consisting of a degasser, a quaternary pump, a column compartment thermostat set at $40{ }^{\circ} \mathrm{C}$, and a diode array detector operated at $200-300 \mathrm{~nm}$ on a Merck (Darmstadt, Germany) Purospher STAR RP-18e column $(55 \times 4-\mathrm{mm}$ I.D. with $3-\mu \mathrm{m}$ particles $)$ protected by a $4 \times 2$ $\mathrm{mm} \mathrm{C} 8$ guard column. The mobile phase consisted of water (solvent A) and methanol (solvent B), both containing $0.05 \%$ trifluoroacetic acid. The flow rate was $1.0 \mathrm{~mL}$ $\min ^{-1}$ with the following linear gradient program: $0 \mathrm{~min}$, $2 \% \mathrm{~B} ; 5 \mathrm{~min}, 2 \% \mathrm{~B} ; 5.1 \mathrm{~min}, 70 \% \mathrm{~B} ; 7 \mathrm{~min}, 70 \% \mathrm{~B}$; $7.1 \mathrm{~min}, 2 \% \mathrm{~B}$; stop time, $17 \mathrm{~min}$. The injection volume was $10 \mu \mathrm{L}$. The cylindrospermopsin in the samples was identified by comparing the retention time (2.04-2.09 $\mathrm{min}$ depending on the individual column used) and UV spectrum (200-300 nm with an absorption maximum at $262 \mathrm{~nm}$ ) with those of the pure cylindrospermopsin standard (CRM-CYN, Institute for Marine Biosciences (NRC-IMB), Halifax, Canada). Linearity of the standard curve was tested by analyzing undiluted $30 \mu \mathrm{M}\left(12.5 \mu \mathrm{gmL}^{-1}\right) \mathrm{CRM}-\mathrm{CYN}$ as well as aqueous dilutions of CRM-CYN (1:10, 1:50, 1:100, 1:200). CRM-CYN and its aqueous dilutions were used as external standards embedded in the sample sequence. CYN concentrations in the extracted lake water samples were quantitated by a comparison of the CYN peak area to those of CRM-CYN and its aqueous dilutions.

HPLC-MS/MS analysis The HPLC-MS/MS experiments were carried out on an Agilent Technologies (Waldbronn, Germany) 1200 Rapid Resolution (RR) LC coupled to a Bruker Daltonics HCT Ultra Ion Trap MS (Bremen, Germany) with electrospray (ESI) source. The 1200 RR LC system included a binary pump, a vacuum degasser, an SL autosampler, and a column compartment thermostat set at $40{ }^{\circ} \mathrm{C}$. The separation of the toxins was achieved with a Supelco (Bellefonte, PA, USA) Ascentis C18 column, (50× $3-\mathrm{mm}$ I.D. with $3-\mu \mathrm{m}$ particles) protected by a $4 \times 2-\mathrm{mm} \mathrm{C} 8$ guard column. The mobile phase consisted of solvents A (99\% water, $1 \%$ acetonitrile, $0.1 \%$ formic acid) and B (acetonitrile, $0.1 \%$ formic acid; following linear gradient program: $0 \min 0 \% \mathrm{~B}, 2.5 \min 0 \% \mathrm{~B}, 2.6 \min 50 \% \mathrm{~B}$, $4 \min 50 \%$ B, $4.1 \min 0 \% \mathrm{~B}$; stop time, $10 \mathrm{~min}$ ). The flow rate was $0.5 \mathrm{mLmin}^{-1}$ and the injection volume was $5 \mu \mathrm{L}$.

The ion trap was operated utilizing the positive electrospray ion mode. The ion source parameters were set as follows: dry temperature, $350{ }^{\circ} \mathrm{C}$; nebulizer pressure, $40 \mathrm{psi}$; and dry gas flow, $10.0 \mathrm{~L} \mathrm{~min}^{-1}$. The capillary voltage 
Table 2 Stability of CYN during the extraction procedure

\begin{tabular}{lll}
\hline Cycle & $\begin{array}{l}\text { CYN as detected by HPLC- } \\
\text { DAD, average } \pm \text { SD }[\mu \mathrm{g} \mathrm{mL}-1]\end{array}$ & $\begin{array}{l}\text { Normalized HPLC- } \\
\text { DAD result } \pm \text { RSD }[\%]\end{array}$ \\
\hline 1 & $3.39 \pm 0.026$ & $100.0 \pm 0.8$ \\
2 & $3.38 \pm 0.11$ & $99.7 \pm 3.2$ \\
3 & $3.29 \pm 0.23$ & $97.1 \pm 7.0$ \\
\hline
\end{tabular}

Four-microgram samples of purified CYN $(n=2)$ were dissolved in $1.2 \mathrm{~mL}$ methanol containing $0.1 \%$ trifluoroacetic acid and exposed to three sonication, evaporation, and redissolving cycles. See "HPLC analysis" section for details

$R S D$ relative standard deviation

was set at $4.0 \mathrm{kV}$. The MS scan range was 395 to $\mathrm{m} / \mathrm{z} 440$ and an MS/MS fragmentation of the target mass $m / z 416$ was employed to obtain the MS/MS spectra. The ICC target was set to 200,000 with a maximum accumulation time of $100 \mathrm{~ms}$.

Cylindrospermopsin was identified in the samples by comparing the retention time and the MS/MS fragmentation with those of pure cylindrospermopsin standards. CRMCYN $(30 \mu \mathrm{M})$ as well as 1:10, 1:25, 1:50, 1:100, 1:200, $1: 400,1: 600$, and 1:800 aqueous dilutions of CRM-CYN were used to test the linearity and the detection limits of the MS and MS/MS signals, and/or as standards to quantify CYN in the water samples. As there is no isotope-labeled CYN standard available, the CYN standards were embedded in the sample sequence as external standards. The standards consisted of pure CYN in water, and there was no attempt to use matrix-matched standards as the characteristics of the studied waters were highly heterogenous. The possible matrix effects in the lake water sample extracts were thus not addressed. However, as the samples injected were fairly dilute and the extraction solvent, acidified methanol, was chosen to minimize coeluting substances (Spoof et al. 2006), no heavy matrix effects were expected. Areabased quantitation of CYN in the lake water samples utilized the MS/MS transition from $\mathrm{m} / \mathrm{z} 416$ to $\mathrm{m} / \mathrm{z} 194$ characteristic for CYN. The retention time of CYN was $1.70-1.73 \mathrm{~min}$ (depending on the batch of eluents and the age of the column). The CYN concentrations obtained (micrograms
CYN per liter) were subsequently standardized to wet weight biomass.

\section{Molecular analysis}

For the qualitative studies, two genes were selected: $c y r \mathrm{~J}$ (gene of sulfotransferases), which is specific for CYNproducing strains and had previously been used for preliminary molecular identifications of this type of cyanobacteria in two Polish lakes (Mankiewicz-Boczek et al. 2012) and the $p k s$ gene, which is required for the synthesis of polyketide metabolites in cyanobacteria (Schembri et al. 2001). For the quantitative analysis, the amidinotransferase coding cyrA gene (Mihali et al. 2008), was used. The gene is involved in the very first steps of cylindrospermopsin biosynthesis and has been confirmed as a suitable target for qPCR analysis also by others (Al-Tebrineh et al. 2012). Using more than one target gene is likely to be more reliable and give stronger evidence that toxigenic genotypes occurred in the sample when positive results are received. Moreover, if both $c y r \mathrm{~J}$ and $c y r \mathrm{~A}$ genes are determined, it is more probable that a complete cyr cluster is present, than if only one target gene was used.

\section{Qualitative analysis of cyrJ and pks genes}

Sample preparation The total genomic DNA was extracted from 72 water samples, six C. raciborskii cultures and $11 A$. gracile cultures according to the methodology of Giovannoni et al. (1990), with some modifications described by Mankiewicz-Boczek et al. (2012).

Cyr $J$ and pks genes amplification The fragment of the sulfotransferase gene cyrJ (578 bp) was amplified with the primer pair cynsulfF (5'-ACTTCTCTCCTTTCCCTATC-3') and cylnamR (5' GAGTGAAAATGCGTAGAACTTG-3'), described previously by Mihali et al. (2008).

The fragment of the $p k s$ gene (422 bp) was amplified with the primer pair K18 (5'-CCTCGCACATAGCCATTTGC-3') and M4 (5'-GAAGCTCTGGAATCCGGTAA-3'), described previously by Fergusson and Saint (2003).

Table 3 Efficiency of the extraction procedure

\begin{tabular}{lllll}
\hline $\begin{array}{l}\text { Extraction } \\
\text { round }\end{array}$ & $\begin{array}{l}\text { Cumulative CYN extracted as } \\
\text { detected by HPLC-DAD, } \\
\text { average } \pm \text { SD }[\mu \mathrm{g}]\end{array}$ & $\begin{array}{l}\text { Normalized HPLC- } \\
\text { DAD result } \pm \text { RSD [\%] }\end{array}$ & $\begin{array}{l}\text { Cumulative CYN extracted as detected } \\
\text { by HPLC-MS/MS, average } \pm \text { SD [ } \mu g]\end{array}$ & $\begin{array}{l}\text { Normalized HPLC- } \\
\text { MS/MS result } \pm \text { RSD [\%] }\end{array}$ \\
\hline 1 & $0.469 \pm 0.047$ & $100.0 \pm 10.0$ & $0.436 \pm 0.037$ & $93.0 \pm 8.5$ \\
2 & $0.427 \pm 0.049$ & $91.0 \pm 11.5$ & $0.409 \pm 0.039$ & $87.2 \pm 9.5$ \\
3 & $0.398 \pm 0.024$ & $84.9 \pm 6.0$ & $0.388 \pm 0.017$ & $82.7 \pm 4.4$ \\
\hline
\end{tabular}

One hundred-milliliter samples of Anabaena lapponica 966 culture were filtered on GF/C filters which were freeze-dried, halved, extracted, and analyzed chromatographically as described in "HPLC analysis" section. Average \pm SD of five filter halves extracted (two injections of each extract). The culture used in this experiment contained 9.4/8.7 $\mu \mathrm{g}$ CYN per liter (HPLC-DAD and HPLC-MS/MS results, respectively) 
Table 4 Precision of the complete analytical method

\begin{tabular}{|c|c|c|c|c|}
\hline Culture & $\begin{array}{l}\text { Analysis by HPLC-DAD, } \\
\text { day } 1 \text {, average } \pm \text { SD }\left[\mu \mathrm{gL}^{-1}\right]\end{array}$ & $\begin{array}{l}\text { Analysis by HPLC-DAD, day } \\
2 \text {, average } \pm \mathrm{SD}\left[\mu \mathrm{gL}^{-1}\right]\end{array}$ & $\begin{array}{l}\text { Analysis by HPLC-MS/MS, } \\
\text { day } 1 \text {, average } \pm S D\left[\mu \mathrm{gL}^{-1}\right]\end{array}$ & $\begin{array}{l}\text { Analysis by HPLC-MS/MS, } \\
\text { day } 2 \text {, average } \pm S D\left[\mu \mathrm{gL}^{-1}\right]\end{array}$ \\
\hline \multicolumn{5}{|l|}{ Anabaena } \\
\hline Full strength & $7.07 \pm 0.40$ & $7.25 \pm 0.78$ & $6.79 \pm 0.77$ & $6.80 \pm 0.78$ \\
\hline Dilute & $1.01 \pm 0.20$ & $1.00 \pm 0.10$ & $1.13 \pm 0.34$ & $1.01 \pm 0.14$ \\
\hline \multicolumn{5}{|c|}{ Cylindrospermopsis } \\
\hline Full strength & $4.40 \pm 0.78$ & $4.41 \pm 0.54$ & $3.89 \pm 0.62$ & $3.91 \pm 0.52$ \\
\hline Dilute & $0.58 \pm 0.03$ & $0.50 \pm 0.04$ & $0.56 \pm 0.06$ & $0.48 \pm 0.05$ \\
\hline
\end{tabular}

One to two hundred-milliliter samples of Anabaena lapponica 966 and C. raciborskii CSIRO 506 cultures were filtered on GF/C filters which were freeze-dried, halved, extracted, and analyzed chromatographically as described in the "HPLC analysis" section. Average \pm SD of five filters extracted (two injections of each extract)

The PCR was performed in a $25-\mu \mathrm{L}$ reaction mix containing 1X PCR buffer (Qiagen), $2.5 \mathrm{mM} \mathrm{MgCl} 2,0.2 \mathrm{mM}$ dNTPs (Qiagen), $10 \mathrm{pmol} \mu \mathrm{L}^{-1}$ of each primer (cyrJ gene) or $20 \mathrm{pmol}$ $\mu \mathrm{L}^{-1}$ of each primer ( $p k s$ gene), $1 \mu \mathrm{L}$ of DNA (DNA concentration was in the range of $100-350 \mathrm{ng}), 0.1 \mathrm{mgmL}^{-1}$ concentration of bovine serum albumin (Fermentas) and $0.8-1 \mathrm{U}$ of Taq DNA polymerase (Qiagen) in a Mastercycler gradient (Eppendorf). An initial denaturation step at $94{ }^{\circ} \mathrm{C}$ for $3 \mathrm{~min}$ (cyrJ gene) or $5 \mathrm{~min}$ (pks gene) was followed by 30 cycles of DNA denaturation at $94{ }^{\circ} \mathrm{C}$ for $10 \mathrm{~s}$, primer annealing at $57^{\circ} \mathrm{C}$ (cyrJ gene) or $60^{\circ} \mathrm{C}$ (pks gene) for $20 \mathrm{~s}$, strand extension at $72{ }^{\circ} \mathrm{C}$ for $1 \mathrm{~min}$ and a final extension step at $72^{\circ} \mathrm{C}$ for $7 \mathrm{~min}$. The PCR products were separated by $1.5 \%$ agarose gel electrophoresis and stained with ethidium bromide $\left(0.5 \mathrm{ngL}^{-1}\right)$.

\section{Quantitative analysis of the cyrA gene}

Sample preparation Twenty-milliliter aliquots of water samples were filtered onto $25-\mathrm{mm}$ diameter $\mathrm{GF} / \mathrm{C}$ filters (Whatman, UK), washed once with $20 \mathrm{~mL}$ of deionized water and stored frozen in $2-\mathrm{mL}$ tubes $\left(-20^{\circ} \mathrm{C}\right)$ until further processing. The filters were suspended in $1.5 \mathrm{~mL}$ of sterile deionized water and heated for $10 \mathrm{~min}$ at $80{ }^{\circ} \mathrm{C}$ to release DNA from the cyanobacterial cells. The liquid was transferred to new tubes and kept frozen $\left(-20^{\circ} \mathrm{C}\right)$ until the qPCR analysis of the cyrA gene.

CyrA gene amplification The primers used to amplify a 103-bp fragment from the cyrA gene (cyrAdF1 (5'GGGACAAAAGTACAATCAATGTGGG-3') and cyrAdR1 ( $5^{\prime}$-TTCGCTGGCTCAAACGGC-3')), as well as a probe-quencher oligonucleotide pair (cyrAPC (5'aminoC6-CTAGTGGGAAGTGAATATCATGCACGPhos-3') and cyrAQC (5'-TGATATTCACTTCCCACTAGBHQ1 $\left.{ }^{\circledR}-3^{\prime}\right)$ ), were designed to hybridize with both Cylindrospermopsis and Aphanizomenon sequences and were based on cyrA sequences available in the GenBank Nucleotide database (retrieved in February 2010). All the oligonucleotides were manufactured by Biomers.net, Ulm, Germany. The probe was labeled at the amino-modified 5'end with an intrinsically fluorescent terbium chelate, as described previously by Nurmi et al. (2002).

The quantitative PCR was performed in a $20-\mu \mathrm{L}$ qPCR reaction mixture consisting of DyNAzyme II HotStart buffer, $0.4 \mathrm{mM}$ dNTPs, $0.2 \mathrm{U}$ of DyNAzyme II HotStart polymerase (all supplied by Finnzymes, Espoo, Finland), $0.4 \mu \mathrm{M}$ primers, $20 \mathrm{nM}$ probe, $280 \mathrm{nM}$ quencher, and $4 \mu \mathrm{L}$ of template. The remaining reaction volume of $20 \mu \mathrm{L}$ was filled with sterile deionized water. All reactions were run on ThermoFast 96 Robotic PCR Plates (Abgene, Surrey, UK) with Applied Biosystems Optical Caps (Foster City, CA, USA). The quantification standards, cyrA PCR products from C. raciborskii CS505 (CSIRO, Hobart, Australia), were produced in PCR reactions as described above (without probe and quencher), purified with a Qiaquick PCR purification kit (Qiagen, Hilden, Germany) and quantified with a Quant-iT PicoGreen dsDNA kit (Invitrogen Molecular Probes, Eugene, OR, USA) according to the manufacturer's instructions. The initial denaturation at $95^{\circ} \mathrm{C}$ for $5 \mathrm{~min}$ was followed by 40 cycles of denaturation at $95{ }^{\circ} \mathrm{C}$ for $30 \mathrm{~s}, 62{ }^{\circ} \mathrm{C}$ for $1 \mathrm{~min}$ and a lowering of the temperature to $35^{\circ} \mathrm{C}$ for 15 measurements every secondcycle beginning after cycle 8 . The thermal cycling was performed in a PTC-200 Peltier Thermal Cycler (MJ Research, Watertown, MA, USA), and the measurements were recorded with a Victor2 Multilabel Counter (PerkinElmer Life Sciences, Wallac, Turku, Finland) using the standard protocol for timeresolved measurement of $\mathrm{Tb}$ fluorescence. The reactions were further assessed for PCR products of the correct size with $2 \%$ agarose gel electrophoresis that was stained with ethidium bromide $\left(0.5 \mathrm{ngL}^{-1}\right)$. Purified cyrA PCR products were used to generate the standard curve. A dilution series of $10^{7}, 10^{6}$, $10^{5}, 10^{4}, 10^{3}, 10^{2}, 10^{1}$ and five copies of cyrA amplicon per reaction were used to generate the standard curve (triplicate reactions in three separate runs). Threshold cycles $(\mathrm{Ct})$ were plotted against log cyrA copy numbers $(y=-3.358 x+38.961$, $\left.R^{2}=0.999\right)$. The efficiency $(E)$ was calculated from the slope of 
the linear regression $\left(E=10^{(-1 / \text { slope })}-1\right.$, where the value

1.00 corresponds to an efficiency of $100 \%$ ).

The cyrA copies per liter of lake water obtained (copies cyrA per liter) were subsequently standardized to $A$. gracile wet weight biomass parameter (copies cyrA per milligram).

\section{CyrJ gene sequence analysis}

The PCR-generated fragments of cyrJ from the A. gracile culture from Strzyżewskie Lake were used for sequencing according to Mankiewicz-Boczek et al. (2012). The homology searches were performed using the National Center for Biotechnology Information microbial and nucleotide Basic Local Alignment Search Tool (BLAST) network service (http://blast.ncbi.nlm.nih.gov/ Blast.cgi) (Zhang et al. 2000).

\section{Data analysis}

We assumed the HPLC-MS/MS data to be the most reliable and the least prone to false positive results (Bláhová et al. 2009); therefore, only these CYN data were used for statistical analysis.

General linear models (GLMs) for explaining the variability in the amount of cylindrospermopsin in the water were constructed from the measured physicochemical variables as well as total algal biomass separately for the two sampling periods. All variables (except $\mathrm{pH}$ ) were logtransformed prior to analyses in order to improve the normality in the residuals. The best-approximating models were identified using the Akaike's Information Criterion (AIC, Burnham and Anderson 2002). Model selection was conducted using both backward and forward procedures in $\mathrm{R}$ (www.r-project.org, function stepAIC).

Spearman rank correlation coefficients analysis was carried out to examine the correlation between particulate concentrations of $\mathrm{CYN}$ and the number of cyrA gene copies and the biomass of potential CYNproducers, as well as between concentrations of $\mathrm{CYN}$ and the percent biomass contribution of these cyanobacteria species to the total phytoplankton biomass. The statistical analyses were performed using the Statistica v. 8 software package (StatSoft, Poland).

$T$ test was conducted to determine whether the lakes in which CYN was detected differed physicochemically from the lakes from which it was absent and to determine whether CYN concentration detected in lakes differed between two studied periods. Prior to analysis, variables were log-transformed to better approximate normality of the residuals.

\section{Results}

Cylindrospermopsin concentration

\section{Evaluation of chromatographic methodology}

CYN in purified form was considered to be stable in the conditions used for the extraction (Table 2). Concerning the extraction of the filtered water samples, one extraction round gave the highest CYN recoveries (Table 3 ). The lower cumulative CYN values observed during the subsequent extraction rounds were unexpected but thought to result from CYN adsorption onto various surfaces during the manipulations of the extracts. The values detected by HPLC-DAD were somewhat higher than those detected by HPLC-MS/MS (Tables 3 and 4) indicating either a coelution of an interfering peak in HPLC-DAD or matrixcaused ionization suppression of CYN in HPLC-MS/MS. As more diluted samples gave homogenous results between the HPLC-DAD and HPLC-MS/MS analysis (Table 4), it is obvious that ion suppression was causing the lower values as detected by HPLC-MS/MS. The precision of the complete analytical procedures fulfilled the needs of this study as the relative standard deviations were typically below $20 \%$ and in many cases much better (Table 4). Parameters relating to the chromatographic performance and detection characteristics (limits of detection and quantitation, linearity) of the methods are given in Table 5.

\section{Water samples}

The ELISA tests revealed CYN presence in 16 and 15 out of 36 lakes at the beginning and end of the summer, respectively, with concentrations ranging from 0.04 to $2.1 \mathrm{\mu gL}^{-1}$. In 12 lakes, this toxin was found during both seasonal periods. In general, the concentration of dissolved CYN was higher than the particulate concentration (Tables 6 and 7).

The extracted ion chromatograms (Fig. 2) and the characteristic MS/MS fragmentation pattern of CYN (Fig. 3a, b) confirmed the ELISA results of particulate CYN in six lakes at the beginning of the summer and nine lakes at the end of the summer (including trace levels). In addition, the HPLC$\mathrm{MS} / \mathrm{MS}$ revealed the presence of $\mathrm{CYN}$ in three lakes that were not detected by ELISA. The particulate concentrations of CYN detected by HPLC-MS/MS were lower in many samples than those identified by ELISA, ranging from trace levels to $3.0 \mu \mathrm{gL}^{-1}$ (Tables 6 and 7).

The HPLC-DAD method (with a detection limit of $0.23 \mu \mathrm{gL}^{-1}$ ) revealed CYN in six of these positive results, ranging from 0.28 to $3.13 \mu \mathrm{gL}^{-1}$.

During both study periods, the maximum particulate CYN content reached $1 \mu \mathrm{gmg}^{-1}$ wet weight. 
Table 5 Chromatographic parameters and detection limits for CYN (typical values)

\begin{tabular}{|c|c|c|c|}
\hline Parameter & HPLC-DAD & $\begin{array}{l}\text { HPLC-MS } \\
(m / z 416)\end{array}$ & $\begin{array}{l}\text { HPLC-MS/MS } \\
\text { (transition from } \\
\mathrm{m} / \mathrm{z} 416 \text { to } \mathrm{m} / \mathrm{z} \text { 194) }\end{array}$ \\
\hline Retention time $[\mathrm{min}]$ & 2.05 & 1.74 & 1.74 \\
\hline Retention factor & 3.36 & 3.14 & 3.14 \\
\hline Resolution (previous peak vs. CYN) & $2.07 / 1.58^{\mathrm{a}}$ & $\mathrm{b}$ & $\mathrm{b}$ \\
\hline Resolution (CYN vs. next peak) & $1.80 / 1.70^{\mathrm{a}}$ & $\mathrm{b}$ & $\mathrm{b}$ \\
\hline Limit of detection $(S / N=3)[\mathrm{ng}$ per injection] & 0.57 & $0.012^{\mathrm{c}}$ & $(\text { Below } 0.078)^{\mathrm{d}}$ \\
\hline Procedural limit of detection $(S / N=3)\left[\mu \mathrm{gL}^{-1}\right.$ lake water $]$ & 0.23 & $0.0094^{\mathrm{c}}$ & $\left(\right.$ Below 0.062) ${ }^{\mathrm{d}}$ \\
\hline Limit of quantitation $(S / N=10)$ [ng per injection] & 1.92 & $0.039^{\mathrm{c}}$ & d \\
\hline Procedural limit of quantitation $(S / N=10)\left[\mu \mathrm{gL}^{-1}\right.$ lake water] & 0.76 & $0.031^{\mathrm{c}}$ & d \\
\hline $\begin{array}{l}\text { Linearity } R^{2} / \text { tested range [ng per injection; corresponding } \\
\text { to } \mu \mathrm{gL}^{-1} \text { lake water] }\end{array}$ & $\begin{array}{l}0.9999 / 0.625-125 \\
0.25-50\end{array}$ & $\begin{array}{l}0.9975 / 0.078-62.5 \\
0.062-50\end{array}$ & $\begin{array}{l}0.9987 / 0.078-62.5 \\
0.062-50\end{array}$ \\
\hline
\end{tabular}

${ }^{a}$ The first value concerns the extract of Anabaena lapponica 966 and the second value the extract of C. raciborskii CSIRO 506

${ }^{\mathrm{b}}$ It is not meaningful to report resolution in the case of MS or MS/MS detection as there are no neighboring peaks with the same $m / z$

${ }^{\mathrm{c}}$ Extrapolated from 14 injections of $0.156 \mathrm{ng} C \mathrm{NN}$ per $5 \mu \mathrm{L}$ giving an average $S / N=40.7$

${ }^{\mathrm{d}}$ It is not possible to determine the $S / N$ of the MS/MS signal as the detector generates MS/MS data only when $416 \mathrm{~m} / z$ (CYN) is found in the MS scan. The lowest CYN standard (1:800 dilution, $0.078 \mathrm{ng}$ per $5 \mu \mathrm{L}$ injection, corresponding to $0.062 \mu \mathrm{g}$ CYN per liter of lake water) was clearly visible with intensities exceeding $10^{4}$

CYN was widely present in lakes differing in productivity and mixing regime, with a more frequent occurrence in polymictic lakes (Tables 6 and 7). However, the $t$ tests indicated that the lakes in which CYN was detected did not differ significantly from those in which it was absent regarding physicochemical properties, such as, the mean and maximum lake depth, surface area, nutrient, and chlorophyll $a$ concentrations, $\mathrm{pH}$, water temperature, conductivity, and visibility. Moreover, $t$ test indicated that CYN concentration did not differ significantly between the study periods.

The best-approximating linear models for explaining the amount of cylindrospermopsin in the water incorporated a wide range of factors such as lake area and depth as well as water temperature, visibility, and nutrient concentrations. The best models explained ca. $18 \%$ and $31 \%$ of the variability in the amount of cylindrospermopsin in the beginning of the summer and in the end of the summer, respectively. Analyses revealed that later in the summer, the amount of cylindrospermopsin was related to many nutrient components such as phosphate (positively) and ammonium (positively) while in the beginning of summer cylindrospermopsin was only related to nitrate (negatively). Cylindrospermopsin was related positively to amount of total algal biomass in the studied lakes only in the beginning of the summer (Table 8).

\section{A. gracile and C. raciborskii cultures}

Using the HPLC-MS/MS method, particulate CYN was detected in two out of the 11 strains of $A$. gracile that were isolated and cultured from the studied lakes (Table 9). At the same time, using this method, none of the six isolated C. raciborskii strains showed positive results for particulate CYN. One positive result among the $C$. raciborskii cultures was obtained using the ELISA method (Table 9).

\section{Phytoplankton analysis}

Phytoplankton in the CYN-containing lakes was typically dominated by cyanobacteria. Of the known potential CYN producers, C. raciborskii, Anabaena bergii, A. gracile, A. flos-aque, and A. ovalisporum were detected. $A$. gracile was the most common and occurred in all lakes where CYN was detected in both sampling periods (Tables 6 and 7). C. raciborskii was present in nine lakes, A. flos-aquae in six, and Anabaena bergii in one of the CYN-positive lakes. A. ovalisporum occurred more sporadically and did not occur in lakes where CYN was detected. Among the CYN producers, the biomass of $A$. gracile was highest and positively correlated with $\mathrm{CYN}$ concentration at both the beginning of the summer $(r=$ $0.51, P<0.05)$ and the end of the summer $(r=0.61, P<$ 0.05 ). Additionally, relative contribution of the A. gracile biomass to the total phytoplankton biomass was positively correlated with $\mathrm{CYN}$ concentration during both periods ( $r=0.53, P<0.05$ and $r=0.61, P<0.05$, respectively). The biomass of other potential CYN producers was much lower and was not significantly correlated with the CYN concentration. 


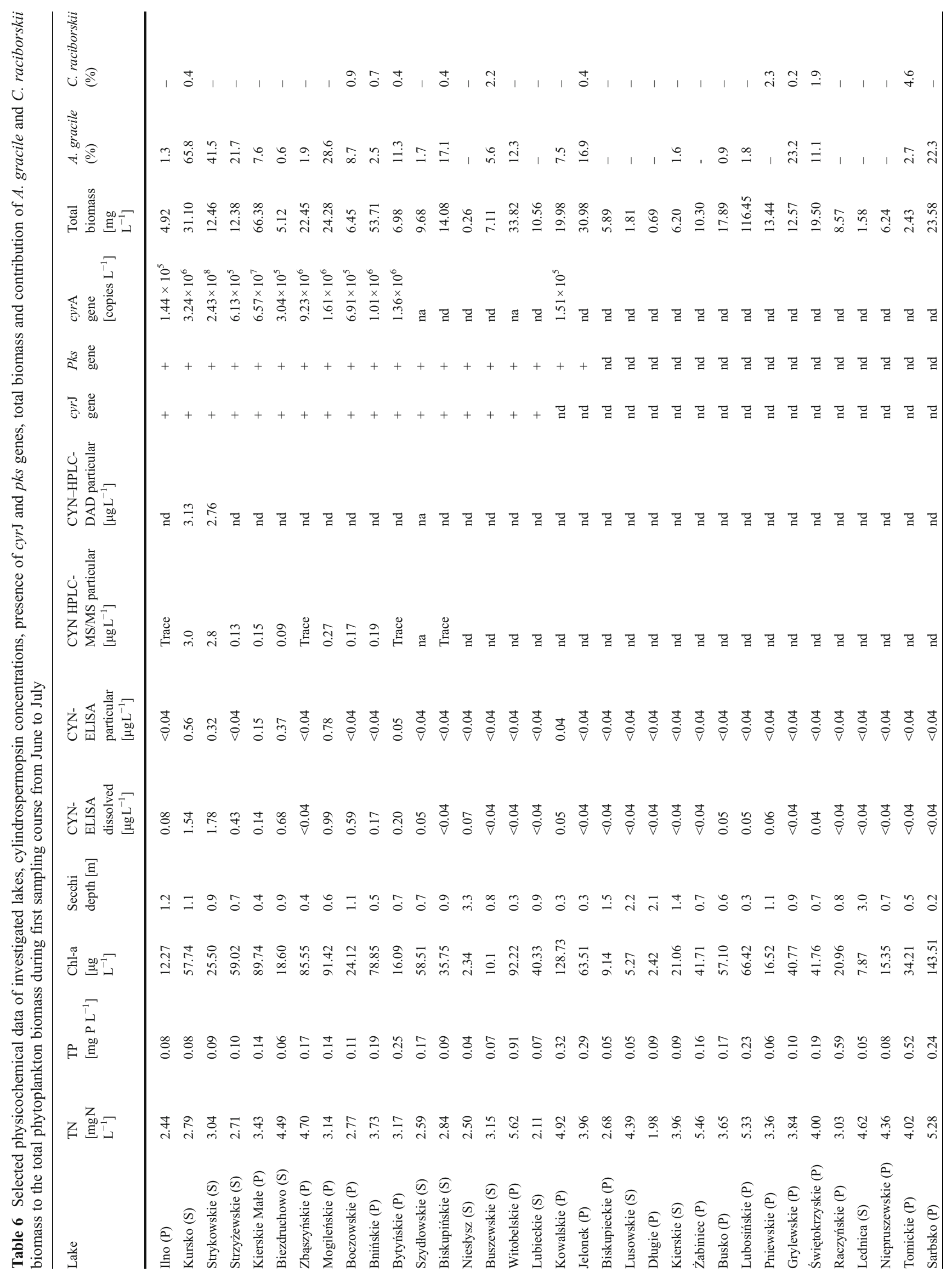




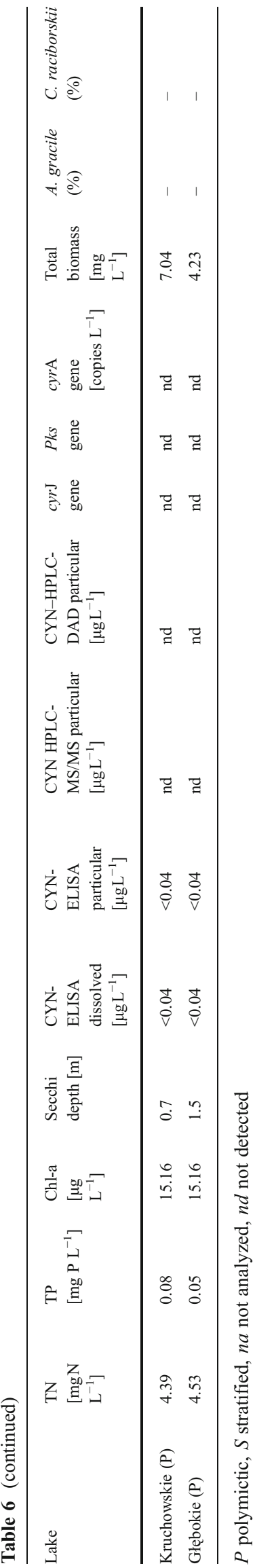

Description of A. gracile and C. raciborskii isolates

The morphology of $A$. gracile and $C$. raciborskii isolates meet the morphological criteria provided by Hindak (2000), Komárek and Komárkova $(2003,2006)$. The A. gracile isolate has a metameric structure-the trichomes are straight, solitary, constricted at cross-wall, and slightly narrowed to the ends (Fig. 4). The cells are short and cylindrical (5-7- $\mu \mathrm{m}$ long and $2-3-\mu \mathrm{m}$ wide) with many small granules and gas vesicles. The apical cells are slightly rounded or conical (3-4- $\mu \mathrm{m}$ long and $1.5-2-\mu \mathrm{m}$ wide). The heterocytes are solitary, intercalar, generally short and cylindrical, sometimes nearly spherical $(3.5-5 \mu \mathrm{m})$. The akinetes are distant from heterocytes, intercalar, cylindrical, and rounded at the poles. They are solitary and always longer $(10-20 \mu \mathrm{m})$ than wide $(4.5-6.5 \mu \mathrm{m})$.

The trichomes of the C. raciborskii isolate are always straight, solitary, slightly constricted at cross-wall. Vegetative cells with well-developed aerotopes are longer $(4-13 \mu \mathrm{m})$ than wide $(2-4 \mu \mathrm{m})$. The heterocytes always developed at the end of trichomes, ovoid, conical, or drop-like shape. The akinetes are oval to cylindrical with rounded ends and granular content occur near the end of trichome (Fig. 5).

Molecular studies

\section{Water samples}

The cyrJ, cyrA, and pks genes associated with CYN production were detected in 25 out of 36 lakes in both sampling periods. The $c y r \mathrm{~J}$ and $c y r \mathrm{~A}$ genes were detected in 17 and 12 lakes, respectively, in June-July (Table 6) and in 18 and 15 lakes, respectively, in August-October (Table 7). In turn, the pks gene was identified in 19 lakes at the beginning (Table 6) and 20 lakes at the end of summer (Table 7). In 13 lakes, all three genes were amplified, including 11 samples at the beginning and 13 samples at the end of the summer (Tables 6 and 7).

All the cyrA PCR products were identified as cyrA based on both the correct size (electrophoresis) and the sequence (qPCR probe). The linear range of detection was $5 \times 10^{0}$ to $1 \times 10^{7}$ cyrA copies per reaction, corresponding to $9.37 \times 10^{4}$ to $1.87 \times 10^{11}$ cyrA copies per liter of lake water. The average amplification efficiency derived from the slope of the standard curve was $98.5 \%$ (sd, $1.2 \%$ ).

The $c y r$ A copies per liter of lake water were significantly positively correlated with $A$. gracile biomass during beginning of summer $(\rho=0.63, p<0.05)$, but the correlation disappeared by the end of summer. Also in the beginning of summer, the cyrA copies referred as gene copies per wet weight biomass of $A$. gracile, were weakly positively associated with CYN content per cell $(\rho=0.39, p<0.05)$, but likewise the correlation was not observed at the end of summer. 


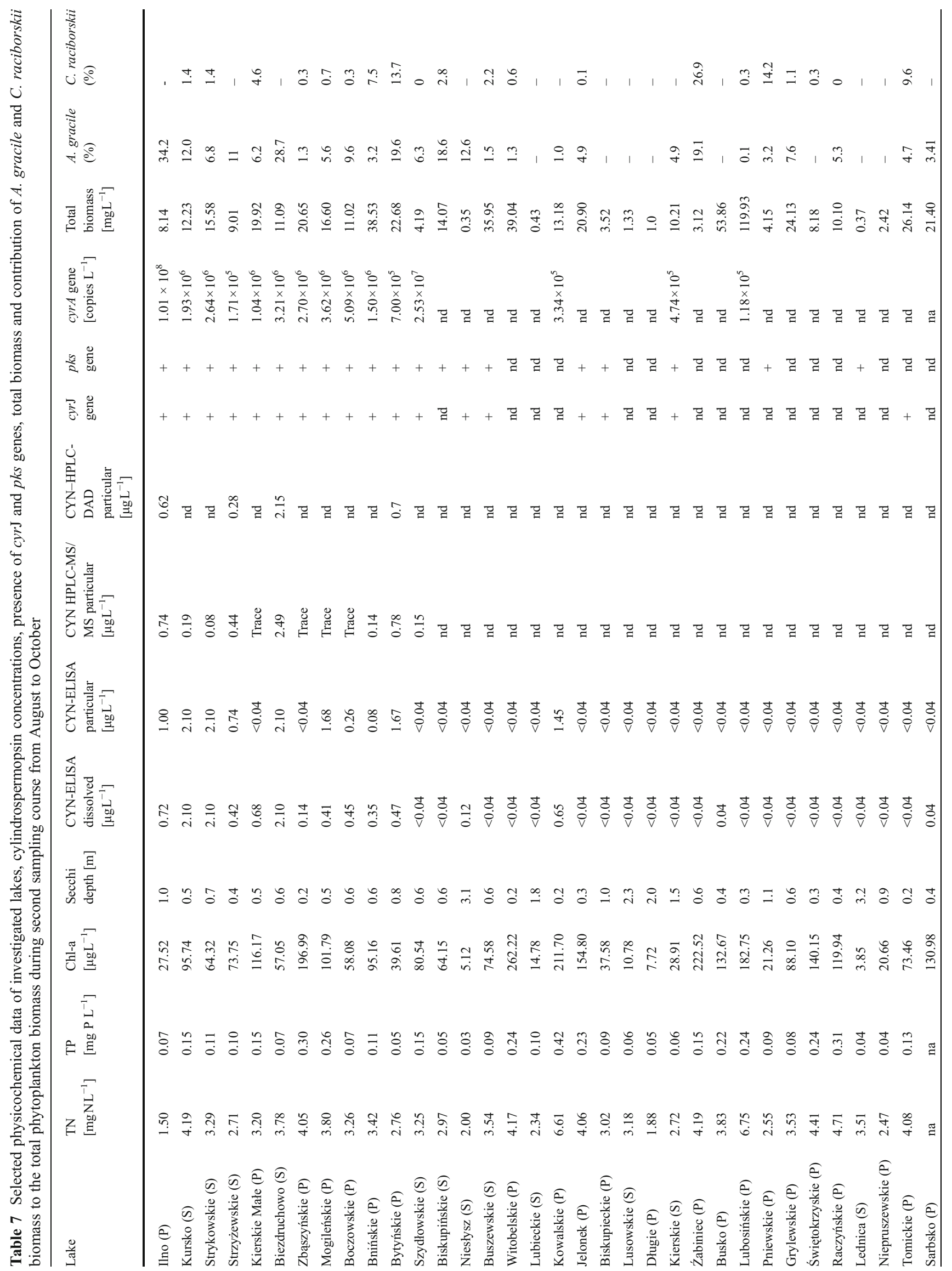




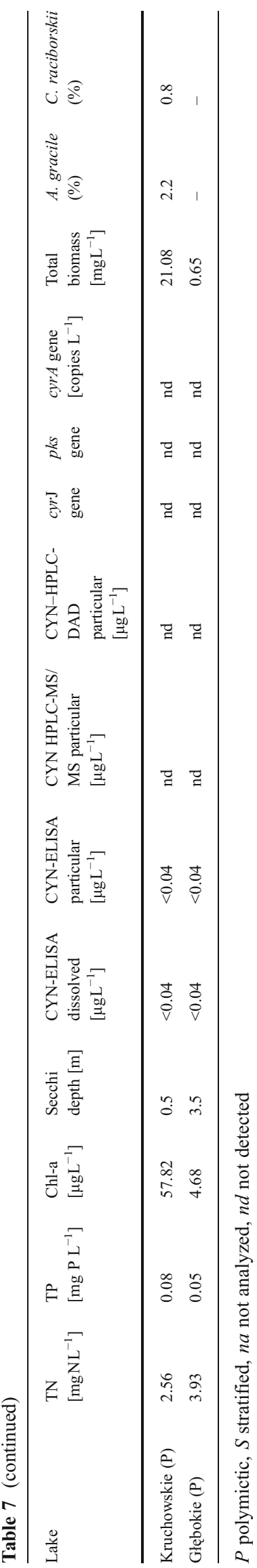

\section{A. gracile and $C$. raciborskii cultures}

The $c y r \mathrm{~J}$ and/or $p k s$ genes were determined in five out of 11 of the $A$. gracile cultures and in two out of six of the $C$. raciborskii cultures. Both the cyrJ and pks genes were detected in DNA isolated from $A$. gracile cultures from the following lakes: Witobelskie, Grylewskie, Strzyżewskie, and Szydłowskie (Table 9).

To confirm the source of the cyrJ gene detected in the water and culture samples, the PCR products from the $A$. gracile culture from Strzyżewskie Lake were subject to cloning and sequencing. The BLAST homology search revealed that the study sequence is $99 \%$ similar to the cyrJ gene of toxic Aphanizomenon sp., strain 10E6 (locus/ GenBank accession number GQ385961).

\section{Discussion}

Knowledge about CYN and its occurrence in Europe has significantly increased during the last decade; however, only a few previous studies have examined a large number of lakes (Fastner et al. 2007; Spoof et al. 2006; Messineo et al. 2009; Bláhova et al. 2009). To our knowledge, the present study is the first to examine CYN occurrence and concentrations across large number of lakes at the northeastern limit of the geographical range of $C$. raciborskii, the potential producer of CYN toxin. Most of the study lakes are used for recreation or they constitute important water supply reservoirs for agriculture farms. These lakes range from meso- to highly eutrophic based on their nutrients levels, chlorophyll $a$ concentrations and Secchi depth visibility. High trophy is due to spatial inflow of nutrients from the cultivated areas and direct waste discharge from agriculture farms during the last decades. The rapid changes of phytoplankton community structure triggered for example by cyanobacteria invasions and toxin production may introduce new threats for human health and disturb ecosystem functioning. Therefore, information on the occurrence and concentration of CYN in natural waters is valuable for evaluation of possible risks for humans and wildlife.

CYN was detected in almost $40 \%$ of the studied lakes, therefore revealing a broader distribution than expected. The previous large-scale studies conducted, for example, in the Czech Republic, Italy, and Finland revealed a narrow distribution of CYN among the studied lakes (Bláhova et al. 2009; Messineo et al. 2009; Spoof et al. 2006). Present results are highly congruent, however, with the study of German lakes, where the common occurrence of CYN (50\% of analyzed lakes) has been documented (Fastner et al. 2007).

There are no enforced or ISO-standardized methods for CYN analysis. Therefore, we decided to use several parallel 


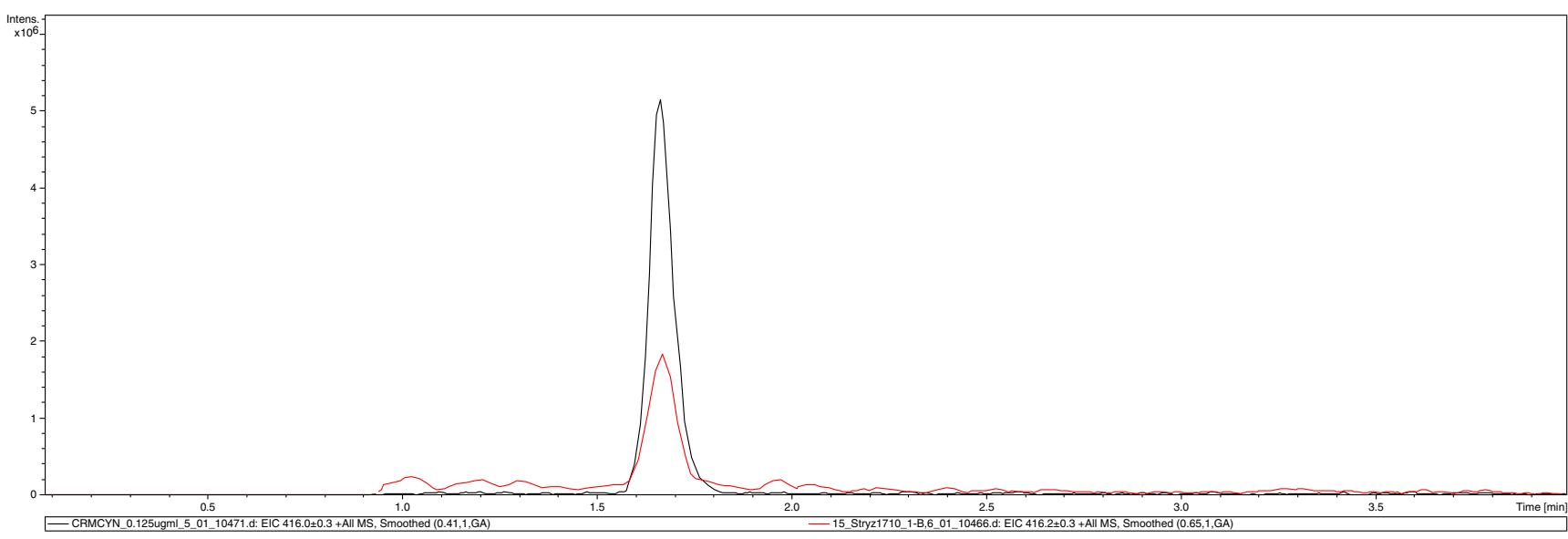

Fig. 2 Extracted ion chromatogram of $\mathrm{m} / \mathrm{z} 416$ of standard CYN (black line, higher peak), $0.625 \mathrm{ng}$ per $5 \mu \mathrm{L}$ injection, and CYN in the sample from Lake Strzyżewskie 17.7.2010 (red line, lower peak) $0.17 \mathrm{ng}$ per $5 \mu \mathrm{L}$ injection

methods in order to achieve reliable results. Screening for CYN was performed with commercial ELISA which has partially unknown cross-reactivity. Trace analysis specifically targeting CYN was performed with HPLC with diode array UV detection (HPLC-DAD) (criteria for identification: retention time and UV spectrum match with CRM-CYN) and HPLC-tandem mass spectrometry (HPLC-MS/MS, criteria for identification: retention time and fragmentation pattern match with CRM-CYN).
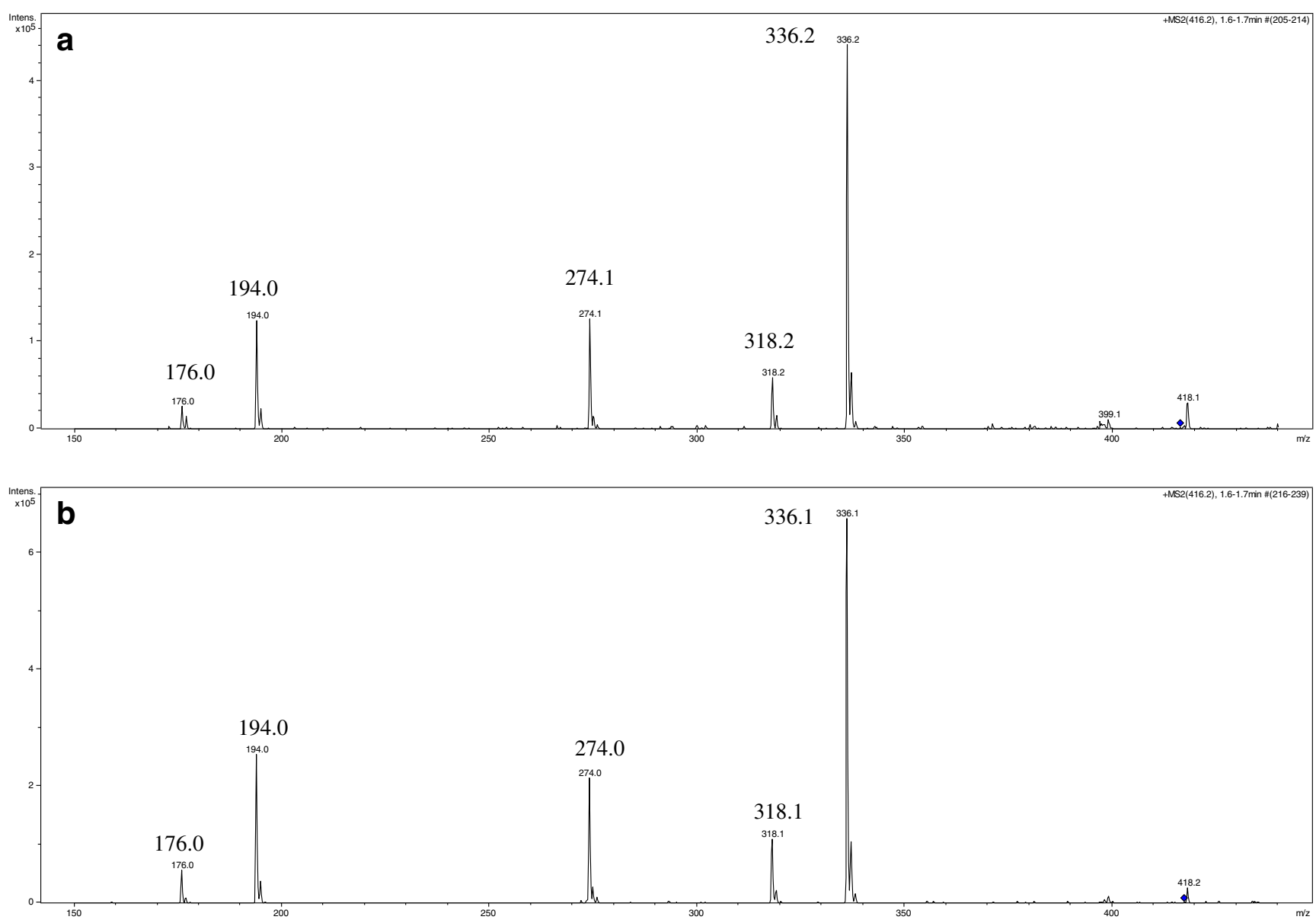

Fig. $3 \mathrm{MS} / \mathrm{MS}$ fragmentation pattern of the precursor ion $\mathrm{m} / \mathrm{z} 416$ a cylindrospermopsin extracted from Lake Strzyżewskie 17.7 .2010 and b cylindrospermopsin standard $0.625 \mathrm{ng}$ per $5 \mu \mathrm{L}$ injection 
Table 8 Three best-approximating general linear models for the relationship between the amount of cylindrospermopsin in the water and associated environmental variables in the beginning of summer and in the end of summer

\begin{tabular}{|c|c|c|c|c|}
\hline Model & AIC & $\triangle \mathrm{AIC}$ & RSE & Adj. $R^{2}$ \\
\hline \multicolumn{5}{|l|}{ Beginning of summer } \\
\hline Depth $^{(+)}+$max_depth ${ }^{(-)}+$volume $^{(+)}+$temperature $^{(+)}+$visibility $^{(+)}+\mathrm{NO}_{3}{ }^{(-)}+$biomass $^{(+)}$ & 75.27 & 0.00 & 0.608 & 0.177 \\
\hline Max_depth ${ }^{(-)}+$volume $^{(+)}+$temperature ${ }^{(+)}+$visibility $^{(+)}+\mathrm{NO}_{3}{ }^{(-)}+$biomass $^{(+)}$ & 75.39 & 0.12 & 0.615 & 0.157 \\
\hline Depth $^{(+)}+$max_depth ${ }^{(-)}+$volume $^{(+)}+$visibility $^{(+)}+\mathrm{NO}_{3}{ }^{(-)}+$biomass $^{(+)}$ & 75.86 & 0.59 & 0.619 & 0.146 \\
\hline \multicolumn{5}{|l|}{ End of summer } \\
\hline $\begin{array}{l}\text { Area }^{(-)}+\text {depth }^{(-)}+\text {max depth } \\
\mathrm{NO}_{3}^{(+)}+\mathrm{NH}_{4}^{(+)}+\mathrm{TN}^{(-)}+\mathrm{PO}_{4}^{(+)}+\mathrm{TP}^{(-)}\end{array}$ & 41.45 & 0.00 & 0.367 & 0.316 \\
\hline $\begin{array}{l}\text { Area }^{(-)}+\text {depth }^{(-)}+\text {max } \text { depth }^{(+)}+\text {volume }^{(+)}+\text {conductivity }^{(+)}+\text {temperature }^{(+)}+ \\
\text {visibility }^{(-)}+\mathrm{NO}_{3}^{(+)}+\mathrm{NH}_{4}^{(+)}+\mathrm{TN}^{(-)}+\mathrm{PO}_{4}^{(+)}+\mathrm{TP}^{(-)}\end{array}$ & 42.23 & 0.78 & 0.369 & 0.310 \\
\hline $\begin{array}{l}\text { Area }^{(-)}+\text {depth }^{(-)}+\text {max depth } \\
\text { temperature } \\
\text { te }^{(+)}+\text {visibility }^{(-)}+\mathrm{NO}_{3}^{(+)}+\mathrm{NH}_{4}^{(+)}+\mathrm{TN}^{(-)}+\mathrm{PO}_{4}^{(+)}+\mathrm{TP}^{(-)}\end{array}$ & 42.79 & 1.34 & 0.370 & 0.310 \\
\hline
\end{tabular}

The directions of the relationships are given in brackets after each variable. Model selection was done using both backward and forward procedures AIC Akaike's Information Criterion

The dissolved CYN concentrations determined by ELISA in our study were higher than the particulate concentrations in most samples, which is in line with other studies (Chiswell et al. 1999; Shaw et al. 1999; Rücker et al. 2007; Wiedner et al. 2008) and indicates both the slow degradation of CYN in the water (Chiswell et al. 1999) and its high water solubility (Sivonen and Jones 1999). The dissolved CYN concentrations determined by ELISA were lower than the values reported from Australia (Chiswell et al. 1999; Shaw et al. 1999) and Germany (Rücker et al. 2007). There are no official regulations established by WHO concerning $\mathrm{CYN}$ concentration in drinking water. Some of the concentrations of CYN observed in this study were, however, higher than the provisional Water Guideline

Table 9 Cylindrospermopsin concentrations, presence of cyrJ and $p k s$ genes in A. gracile and C. raciborskii cultures isolated from the investigated lakes

\begin{tabular}{|c|c|c|c|c|c|}
\hline Lake & $\begin{array}{l}\text { CYN-ELISA } \\
\text { dissolved }\left[\mu \mathrm{gL}^{-1}\right]\end{array}$ & $\begin{array}{l}\text { CYN-ELISA } \\
\text { particular }\left[\mu \mathrm{gL}^{-}\right]\end{array}$ & $\begin{array}{l}\text { CYN HPLC-MS/MS } \\
\text { particular }\left[\mu \mathrm{gL}^{-}\right]\end{array}$ & $\begin{array}{l}\text { cyrJ gene } \\
(578 \mathrm{bp})\end{array}$ & $\begin{array}{l}\text { pks gene } \\
\text { (422 bp) }\end{array}$ \\
\hline \multicolumn{6}{|c|}{ Aphanizomenon gracile } \\
\hline Mogileńskie & 0.038 & $<0.04$ & nd & nd & nd \\
\hline Witobelskie & $<0.04$ & $<0.04$ & nd & + & + \\
\hline Grylewskie & $<0.04$ & $<0.04$ & nd & + & + \\
\hline Kruchowskie & $<0.04$ & $<0.04$ & nd & na & na \\
\hline Strzyżewskie & 0.54 & 1.5 & 0.67 & + & + \\
\hline Buszewskie & $<0.04$ & $<0.04$ & nd & + & nd \\
\hline Szydłowskie & na & na & 0.11 & + & + \\
\hline Kierskie Małe & $<0.04$ & $<0.04$ & nd & nd & nd \\
\hline Lubosińskie & $<0.04$ & $<0.04$ & nd & nd & nd \\
\hline Pniewskie & $<0.04$ & $<0.04$ & nd & nd & nd \\
\hline Jelonek & $<0.04$ & $<0.04$ & nd & na & na \\
\hline \multicolumn{6}{|c|}{ Cylindrospermopsis raciborskii } \\
\hline Niepruszewskie & $<0.04$ & $<0.04$ & nd & nd & nd \\
\hline Boczowskie & 0.17 & $<0.04$ & nd & nd & nd \\
\hline Świętokrzyskie & $<0.04$ & $<0.04$ & nd & nd & + \\
\hline Bytyńskie & $<0.04$ & $<0.04$ & nd & nd & nd \\
\hline Witobelskie & $<0.04$ & $<0.04$ & nd & nd & + \\
\hline Buszewskie & $<0.04$ & $<0.04$ & nd & na & na \\
\hline
\end{tabular}

Cultures harvested in the beginning of the stationary growth phase

na not analyzed, $n d$ not detected 


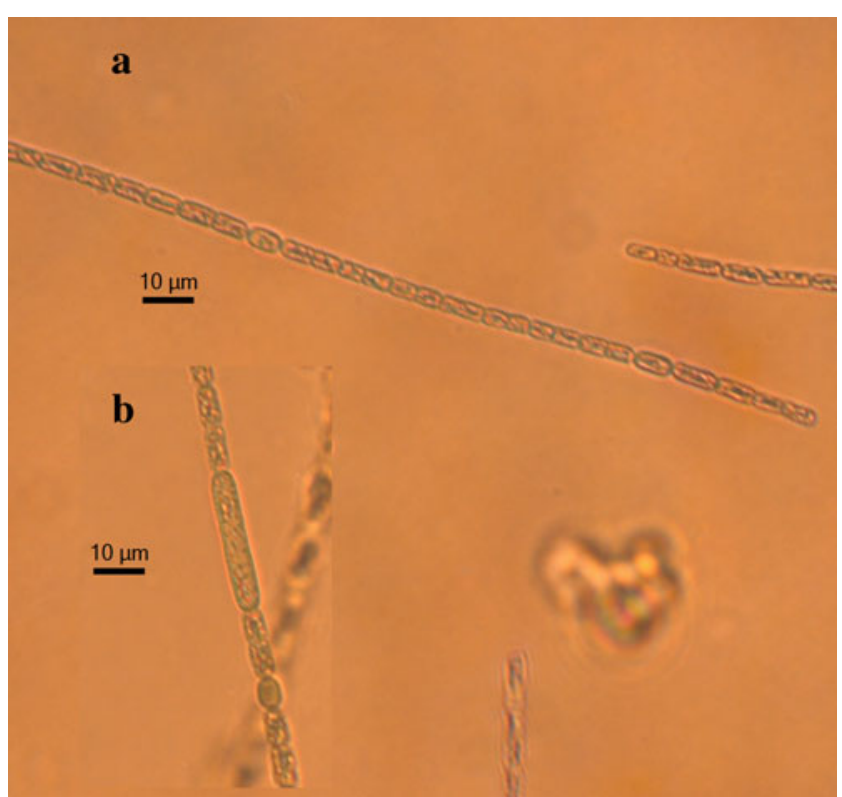

Fig. 4 Photographs of A. gracile strain isolated from Lake Strzyżewskie a filament with two heterocysts and $\mathbf{b}$ fragment of filament with one akinete and heterocyst

Level of $1 \mu \mathrm{gL}^{-1}$ proposed in some countries including Canada (Svrcek and Smith 2004) and Australia (Humpage and Falconer 2003).

The particulate CYN values determined by the ELISA and HPLC-MS/MS were qualitatively highly concordant. However, there were quantitative differences between these two methods as ELISA values were higher in most samples than those detected by HPLC-DAD and HPLC-MS/MS. This might result from undesired cross-reactivity of the antibodies used in ELISA towards, e.g., CYN precursors or other compounds structurally related to CYN. The results of the two chromatographic methods were qualitatively and quantitatively comparable at the higher toxin levels. The

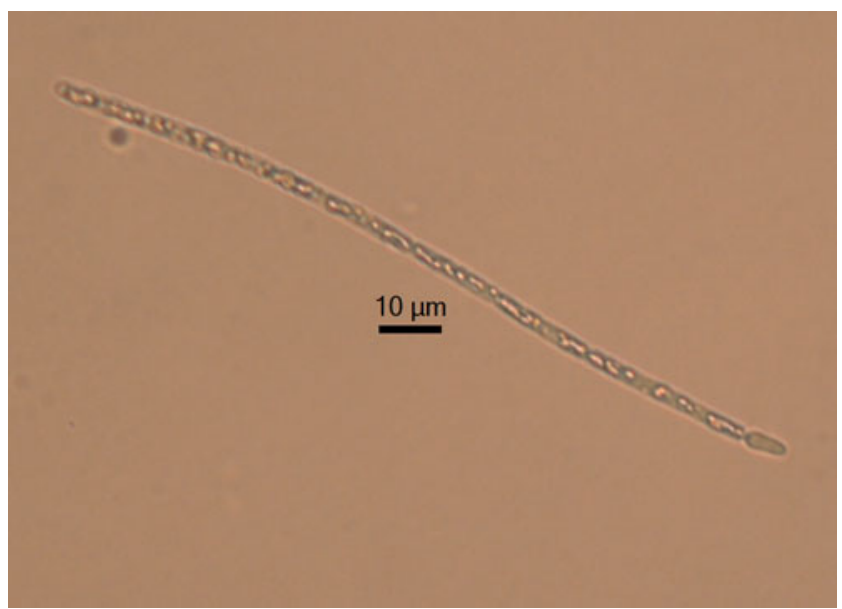

Fig. 5 Photograph of $C$. raciborskii strain isolated from Lake Bytyńskie (filament with one heterocyst) detection limit of HPLC-DAD is higher than those of LCMS/MS or ELISA. At low toxin levels (depending on the lake matrix but generally speaking below $0.5-1 \mu \mathrm{g}$ CYN per liter original lake water sample) the usefulness of the employed HPLC-DAD technique is limited because there is matrix interference and coelution.

There were some positive results from ELISA tests that were not confirmed by the other two methods, e.g., in two $C$. raciborskii cultures. Similar discrepancies were observed by Bláhova et al. (2009). The differences between these methods may result from matrix effects influencing the ELISA test, e.g., the possible cross-reactivity of antibodies with unidentified CYN congeners or isomers in the samples (Yilmaz et al. 2008). Despite this possibility, the present study demonstrated ELISA testing to be a reliable screening method that should, however, be confirmed by HPLC-MS/MS or HPLC-DAD. The particulate CYN concentrations detected by the HPLCMS/MS method reach up to $3.0 \mu \mathrm{gL}^{-1}$. This is higher than the drinking water guideline value of $1 \mu \mathrm{gL}^{-1}$ that was proposed for total CYN by Humpage and Falconer (2003) and is higher than the maximal concentrations $\left(1.79 \mu \mathrm{gL}^{-1}\right)$ observed earlier in this region (Kokociński et al. 2009). However, the observed particulate $\mathrm{CYN}$ concentrations are much lower than the particulate concentrations observed in Australia and Florida (Chiswell et al. 1999; Shaw et al. 1999) or Spain (Quesada et al. 2006) and Italy (Messineo et al. 2009). In contrast, generally lower values of particulate CYN were observed in Germany (Rücker et al. 2007; Wiedner et al. 2008). Overall, when considering total CYN concentrations, the observed values were comparable to the commonly found concentrations of $1-10 \mu \mathrm{gL}^{-1}$ reported by Falconer and Humpage (2006).

To date, very few studies have investigated the relationship between CYN concentration and environmental factors potentially affecting its production. Experimental studies were focused, e.g., on effects of temperature (Saker and Griffiths 2000), nitrogen (Saker and Neilan 2001), or light (Dyble et al. 2006). Our study showed that CYN was detected in lakes that differed widely in terms of productivity, mixing regime, and morphological parameters, but its distribution did not show any distinct spatial pattern across the investigated lakes (Fig. 1). The $t$ tests indicated that the CYN-positive lakes (i.e., lakes where it occurred) did not differ environmentally from the CYNnegative lakes. Moreover, CYN concentrations did not differ significantly between the sampling periods, indicating the ability of the cyanobacteria to produce CYN during the whole summer period under different environmental conditions. Furthermore, GLMs showed a weak relationship between $\mathrm{CYN}$ and the selected environmental factors and contrasting relationships between $\mathrm{CYN}$ concentration and environmental factors in the two study periods. This is in line with another recent study where no strong correlation between morphometrical or environmental factors and CYN occurrence was 
observed (Rücker et al. 2007). According to GLM analyses, CYN was weakly positively related to different mineral forms of nutrients, especially in the end of summer. Conversely, a study by Saker and Neilan (2001) showed intermediate concentration of CYN in C. raciborskii cultures supplied with nitrate and lowest values when supplied with ammonium. These differences could be associated with the different potential producers of CYN in these studies, contradicting in nutrient demands as presented recently by Dolman et al. (2012). In addition to nutrients, our study showed that temperature was positively related to CYN concentration in both studied periods. The role of temperature was recently indicated also by Burford and Davis (2011). However, our work showed that the highest amount of CYN was detected at temperature ranging from 24.7 to $26.5^{\circ} \mathrm{C}$, which disagrees with earlier experimental studies by Saker and Griffiths (2000) and Preußel et al. (2009) who observed the highest $\mathrm{CYN}$ concentrations at $20{ }^{\circ} \mathrm{C}$ and pronounced reduction of $\mathrm{CYN}$ production at increasing temperatures. These contrasting results could be due to the different CYN producers examined in these studies and different regulatory mechanisms of CYN-producing strains involved (Wiedner et al. 2008).

Of the potential producers of CYN, A. flos-aque, A. gracile, A. ovalisporum, Anabaena bergii, and C. raciborskii were identified in the studied lakes. A. gracile and $C$. raciborskii being the most common phytoplankton species in the lakes. Moreover, only the biomass of A. gracile and its contribution to total phytoplankton biomass were positively correlated with particulate $\mathrm{CYN}$ concentrations during both sampling periods and cyrA gene copies during the beginning of summer. The positive correlation coefficient between $A$. gracile and CYN concentration has also been reported for German freshwater lakes (Rücker et al. 2007; Wiedner et al. 2008).

The occurrence of toxigenic genotypes of cyanobacteria capable of producing CYN was confirmed by molecular analysis. All three genes, cyrA, cyrJ and pks, were amplified in almost all of the CYN-positive samples. The cyrJ sulfotransferase gene, in particular, has previously been shown to be reliable for the identification of CYN-producing cyanobacteria (Mihali et al. 2008; Ballot et al. 2011; Mankiewicz-Boczek et al. 2012). This study supports the notion that especially $c y r \mathrm{~J}$, but also $c y r \mathrm{~A}$, can be used as suitable qualitative genetic markers for the determination of toxigenic (potentially toxic) genotypes and therefore can be used to assess the potentiality of cyanobacteria to produce CYN in Polish lakes. Although the cyrA gene has been previously associated with false positive results (Ballot et al. 2011), in this study, the rates of misidentifications for $c y r \mathrm{~A}$ and $c y r \mathrm{~J}$ were similar. The pks gene was more prone to false positives; it was detected in two $C$. raciborskii cultures and many environmental samples, which, however, were CYN negative. In contrast to the findings of recent work, which compared CYN concentrations to the number of $c y r C$ copies per cell in C. raciborskii (Orr et al. 2010), the number of $c y r A$ gene copies referred as gene copies per cell was only weakly correlated with particulate CYN cell content in the beginning of summer, indicating that the amount of CYN was not quantitatively related to the number of $c y r \mathrm{~A}$ gene copies. The lack of the correlation may suggest that nonCYN-producing strains of this cyanobacterium were more abundant than toxic genotypes and that the proportions of these genotypes varied from lake to lake, which is likely, since the correlation between cyrA and A. gracile biomass was shown to vary between the sampling times. Natural variability in gene cell quotas between different species and strains has been shown to vary greatly, a factor which is likely to have an effect on determining correlations between toxin and gene contents (Orr et al. 2010). Additionally, we assumed that CYN was exclusively produced by $A$. gracile, and calculations of gene and CYN cell quotas were made on that basis. Although the cyrA primers and probe used here are capable of detecting Cylindrospermopsis as well as Aphanizomenon, the proportion of the former in the lake biomass was generally very small and earlier studies have indicated that Cylindrospermopsis is not likely to be a major CYN-producing genus in Europe (e.g., Mankiewicz-Boczek et al. 2012). Another possibility to explain the lack of correlation is that there could have been other previously unidentified potential CYN producers in the investigated lakes.

To confirm the identity of the producer of CYN in the studied lakes, the toxicity and toxigenicity of the isolated strains of $A$. gracile and $C$. raciborskii were determined. These analyses (i.e., HPLC-MS/MS and gene amplification) showed that none of the isolated $C$. raciborskii strains had the ability to produce $C Y N$, which is in line with other studies on European strains of this cyanobacterium (Fastner et al. 2003; Bernard et al. 2003; Saker et al. 2003; Antal et al. 2011; Mankiewicz-Boczek et al. 2012). Although, in two cultures of $C$. raciborskii, the pks gene was detected, but due to its nonspecificity (Schembri et al. 2001) and lack of amplification of the cyrJ gene and CYN production, this result was not considered relevant to the study.

CYN occurrence (by HPLC-MS/MS) and toxigenicity (by gene amplification) were observed in $A$. gracile strains isolated from Lakes Strzyżewskie and Szydłowskie, where CYN and all three of the analyzed genes had been observed in the environmental samples. Moreover, the BLAST homology search revealed that the sequence of the amplified $c y r \mathrm{~J}$ gene from the $A$. gracile culture from Lake Strzyżewskie was $99 \%$ similar to the cyrJ gene of the toxic Aphanizomenon sp. strain 10E6 from Germany, which was described by Stüken and Jakobsen (2010). Using both morphological characteristics (Hindak 2000; Komárek 2010) and molecular approaches (Ballot et al. 2010), A. gracile and A. flos-aque are recognized as two separate species. Based on the first criteria, the studied strain from Lake Strzyżewskie was identified as $A$. gracile. To 
our knowledge, this is the first report of a cylindrospermopsinproducing strain of $A$. gracile in Polish lakes. Our results confirm the earlier observation of $A$. gracile being a major potential producer of CYN in German lakes (Rücker et al. 2007; Wiedner et al. 2008).

The genes cyrJ and pks were detected also in the other three cultures of $A$. gracile, but CYN was not produced perhaps due to the regulation of the translation process. Also, changes in growing conditions, such as light intensity, may have influenced the activity of toxic genotypes (Kaebernick et al. 2000). Moreover, similarly to microcystins (Mikalsen et al. 2003), regulation of the synthesis of CYN at the level of translation may have caused the lack of toxin production despite the expression of genes participating in toxin synthesis.

In summary, the present work revealed that CYN commonly occurred in lakes of western Poland throughout the whole summer under varying environmental conditions. Amount of mineral forms of nutrients and temperature seemed to play an important role in CYN production in the investigated lakes. The observed values of particulate CYN were lower than the values reported from Australia, North America, Spain, or Italy but higher than the values observed in Germany. Molecular analysis confirmed the presence of CYN-producing cyanobacteria in the samples in which CYN was detected. Based on HPLC-MS/MS and molecular studies of the A. gracile cultures, A. gracile was found to be the major producer of CYN in the studied lakes. Further studies should be conducted to identify all the potential CYN-producing species and to understand the influence of CYN production on aquatic ecosystems. Monitoring of cylindrospermopsin and its potential producers should be undertaken since CYN constitutes a risk for humans and wildlife.

Acknowledgments The financial support was provided by Polish Ministry of Science and Higher Education through research grants no. N N 304020437 and N N 304014 539. In addition, financial support from Tekes to the Finnish authors, decision number 40193/09, is gratefully acknowledged. We thank Prof. Hindak from the Institute of Botany, Slovak Academy of Sciences for his help in cyanobacteria identification and Niina Perälä, Department of Biotechnology, University of Turku, for the technical assistance in molecular studies.

Open Access This article is distributed under the terms of the Creative Commons Attribution License which permits any use, distribution, and reproduction in any medium, provided the original author(s) and the source are credited.

\section{References}

Al-Tebrineh J, Pearson L, Yasar S, Neilan B (2012) A multiplex qPCR targeting hepato- and neurotoxic cyanobacteria of global significance. Harmful Algae 15:19-25
Antal O, Karisztl-Gácsi M, Farkas A, Kovács A, Ács A, Törő N, Kiss G, Saker ML, Győri J, Bánfalvi G, Vehovszky A (2011) Screening the toxic potential of Cylindrospermopsis raciborskii strains isolated from Lake Balaton, Hungary. Toxicon 57:831-840

APHA (1998) Standard methods for the examinations of water and wastewater, 20th edn. American Public Health Associations, Washington

van Apeldoorn ME, van Egmond HP, Gerrit JA, Speijers A, Bakker GJI (2007) Toxins of cyanobacteria. Review. Mol Nutr Food Res 51:7-60

Ballot A, Fastner J, Wiedner C (2010) Paralytic shellfish poisoning toxin-producing cyanobacterium Aphanizomenon gracile in northeast Germany. Appl Environ Microbiol 76:1173-1180

Ballot A, Ramm G, Rundberget T, Kaplan-Levy RN, Hadas O, Sukenik A, Wiedner C (2011) Occurrence of non-cylindrospermopsinproducing Aphanizomenon ovalisporum and Anabaena bergii in Lake Kinneret (Israel). J Plankton Res 33:1736-1746

Banker R, Carmeli S, Hadas O, Teltsch B, Porat R, Sukenik A (1997) Identification of cylindrospermopsin in Aphanizomenon ovalisporum (Cyanophyceae) isolated from Lake Kinneret. Isr J Phycol 33:613-616

Banker R, Carmeli S, Teltsch B, Sukenik A (2000) 7-Epicylindrospermopsin, a toxic minor metabolite of the cyanobacterium Aphanizomenon ovalisporum from Lake Kinneret, Israel. J Nat Prod 63:387-389

Bazin E, Mourot A, Humpage AR, Fessard V (2010) Genotoxicity of a freshwater cyanotoxin, cylindrospermopsin, in two human cell lines: Caco-2 and HepaRG. Environ Mol Mutagen 51:251-259

Bernard C, Harvey M, Briand JF, Bire R, Krys S, Fontaine JJ (2003) Toxicological comparison of diverse Cylindrospermopsis raciborskii strains: evidence of liver damage caused by a French $C$. raciborskii strain. Environ Toxicol 18:176-186

Blahova L, Oravec M, Marsalek B, Sejnohova L, Simek Z, Blaha L (2009) The first occurence of the cyanobacterial alkaloid toxin cylindrospermopsin in the Czech Republic as determined by immunochemical and LC/MS methods. Toxicon 53:519-524

Bourke ATC, Hawes RB, Neilson A, Stallman ND (1983) An outbreak of the hepatoenteritis (the Palm island mystery disease) possibly caused by algal intoxication. Toxicon (Suppl) 3:45-48

Brient L, Lengronne M, Bormans M, Fastner J (2009) First occurence of cylindrospermopsin in freshwater in France. Environ Toxicol 24:415-420

Burnham KP, Anderson DR (2002) Model selection and inference: a practical information-theoretic approach. Springer, New York

Burford M, Davis TW (2011) Physical and chemical processes promoting dominance of the toxic cyanobacterium Cylindrospermopsis raciborskii. Chin J Oceanol Limnol 29:883-891

Carmichael W, Falconer IR (1993) Diseases related to freshwater bluegreen algal toxins, and control measures. In: Falconer IR (ed) Algal toxins in seafood and drinking water. Academic Press, London, pp 197-209

Chiswell RK, Shaw GR, Eaglesham G, Smith MJ, Norris RL, Seawright AA, Moore MR (1999) Stability of cylindrospermopsin, the toxin from the cyanobacterium, Cylindrospermopsis raciborskii: effect of $\mathrm{pH}$, temperature, and sunlight on decomposition. Environ Toxicol 14:155-161

Chonudomkul D, Yongmanitchai W, Theeragool G, Kawachi M, Kasai F, Kaya K, Watanabe MM (2004) Morphology, genetic diversity, temperature tolerance and toxicity of Cylindrospermopsis raciborskii (Nostocales, Cyanobacteria) strains from Thailand and Japan. FEMS Microbiol Ecol 48:345-355

Dolman AM, Rücker J, Pick FR, Fastner J, Rohrlack T, Mischke U, Wiedner C (2012) Cyanobacteria and cyanotoxins: the influence of nitrogen and phosphorus. PLoS One 7(6):e38757. doi:10.1371

Dyble J, Tester PA, Litaker RW (2006) Effects of light on cylindrospermopsin production in the cyanobacterial HAB species Cylindrospermopsis raciborskii. Afr J Mar Sci 28:309-312

Falconer IR, Hardy SJ, Humpage AR, Froscio SM, Tozer GJ, Hawkins PR (1999) Hepatic and renal toxicity of the blue-green alga 
(cyanobacterium) Cylindrospermopsis raciborskii in male Swiss Albino mice. Environ Toxicol 14:143-150

Falconer IR, Humpage AR (2001) Preliminary evidence for in vivo tumor initiation by oral administration of extracts of the bluegreen alga Cylindrospermopsis raciborskii containing the toxin cylindrospermopsin. Environ Toxicol 16:192-195

Falconer IR, Humpage AR (2006) Cyanobacterial (blue-green algal) toxins in water supplies: cylindrospermopsin. Environ Toxicol 21:299-304

Fastner J, Rücker J, Stüken A, Preussel K, Nixdorf B, Chorus I, Kohler A, Wiedner C (2007) Occurrence of the cyanobacterial toxin cylindrospermopsin in northeast Germany. Environ Toxicol 22:26-32

Fastner J, Heinze R, Humpage AR, Mischke U, Eaglesham GK, Chorus I (2003) Cylindrospermopsin occurrence in two German lakes and preliminary assessment of the toxicity and toxin production of Cylindrospermopsis raciborskii cyanobacteria isolates. Toxicon 42:313-321

Fergusson KM, Saint CP (2003) MultiplexPCR assay for Cylindrospermopsis raciborskii and cylindrospermopsinproducing cyanobacteria. Environ Toxicol 18:120-125

Froscio SM, Humpage AR, Burcham PC, Falconer IR (2003) Cylindrospermopsin-induced protein synthesis inhibition and its dissociation from acute toxicity in mouse hepatocytes. Environ Toxicol 18:243-251

Giovannoni SJ, DeLong EF, Schmidt TM, Pace NR (1990) Tangential flow filtration and preliminary phylogenetic analysis of marine picoplankton. Appl Environ Microbiol 56:2572-2575

Gutiérrez-Praena D, Pichardo S, Moyano R, Blanco A, Monterde JG, Cameán AM (2012) Time-dependent histopathological changes induced in Tilapia (Oreochromis niloticus) after acute exposure to pure cylindrospermopsin by oral and intraperitoneal route. Ecotoxicol Environ Saf 76:102-113

Haande S, Rohrlack T, Ballot A, Roberg K, Skulberg R, Beck M, Wiedner C (2008) Genetic characterization of Cylindrospermopsis raciborskii (Nostocales, Cyanobacteria) isolates from Africa and Europe. Harmful Algae 7:692-701

Harada KI, Ohtani I, Iwamoto K, Suzuki M, Watanabe MF, Watanabe M, Terao K (1994) Isolation of cylindrospermopsin from cyanobacterium Umezakia natans and its screening method. Toxicon 32:73-84

Hawkins PR, Chandrasena NR, Jones GJ, Humpage AR, Falconer IR (1997) Isolation and toxicity of Cylindrospermopsis raciborskii from an ornamental lake. Toxicon 35:341-346

Hawkins PR, Holliday J, Kathuria A, Bowling L (2005) Change in cyanobacterial biovolume due to preservation by Lugol's iodine. Harmful Algae 4:1033-1043

Hindák F (1978) Freshwater algae. Slovenské Pedagogické Nakladatelstwo, Bratislava

Hindák F (2000) Morphological variation of four planktic nostocalean cyanophytes-members of the genus Aphanizomenon or Anabaena? Hydrobiologia 438:107-116

Hötzel G, Croome R (1999) A phytoplankton methods manual for Australian freshwaters. LWRRDC occasional paper 22/99. Land and water resources research and development corporation

Humpage AR, Fenech M, Thomas P, Falconer IR (2000) Micronucleus induction and chromosome loss in transformed human white cells indicate clastogenic and aneugenic action of the cyanobacterial toxin, cylindrospermopsin. Mutat Res 472:155-161

Humpage AR, Falconer IR (2003) Oral toxicity of the cyanobacterial toxin cylindrospermopsin in male Swiss albino mice: determination of no observed adverse effect level for deriving a drinking water guideline value. Environ Toxicol 18:94-103

ISO 10304-1 (2007) In: Water quality-determination of dissolved anions by liquid chromatography of ions. Part 1: Determinations of bromide, chloride, fluoride, nitrate, nitrite, phosphate and sulfate. International Organization for Standardization, Geneva
ISO 6878 (2004) In: Water quality-determination of phosphorusammonium molybdate spectrometric method. International Organization for Standarization, Geneva

Javornicky P (1958) Revise někter ch method pro zjišt'ovănǐkvantity fitoplantonu (Revision of some methods for the phytoplankton quantity estimation). Scientific Paper 2, Faculty of Technology of Fuel and Water, Institute of Chemical Technology, Prague.

Kaebernick M, Neilan BA, Börner T, Dittmann E (2000) Light and the transcriptial response of the microcystin biosynthesis gene cluster. Appl Environ Microbiol 66:3387-3392

Kinnear SHW, Fabbro LD, Duivenvoorden LJ, Hibberd EMA (2007) Multiple-organ toxicity resulting from cylindrospermopsin exposure in tadpoles of the cane toad (Bufo marinus). Environ Toxicol 22:550-558

Kinnear SHW, Fabbro LD, Duivenvoorden LJ (2008) Variable growth responses of water thyme (Hydrilla verticillata) to whole-cell extracts of Cylindrospermopsis raciborskii. Arch Environ Contam Toxicol 54:187-194

Kokociński M, Dziga D, Spoof L, Stefaniak K, Jurczak T, Mankiewicz-Boczek J, Meriluoto J (2009) First report of the cyanobacterial toxin cylindrospermopsin in the shallow, eutrophic lakes of western Poland. Chemosphere 74:669-675

Kokociński M, Soininen J (2012) Environmental factors related to the occurrence of Cylindrospermopsis raciborskii (Nostocales, Cyanophyta) at the north-eastern limit of its geographical range. Eur J Phycol 47:12-21

Komárek J, Anagnostidis K (1989) Modern approach to the classification system of Cyanophytes 4-Nostocales. Arch Hydrobiol Suppl 82-83:247-345

Komárek J, Anagnostidis K (1998) Cyanoprocaryota. Teil: Chroococcales. In: Gärtner EH, Heynigh G, Mollenhauer D (eds) Süßwasserflora von Mitteleuropa 19/1, Gustav Fischer, Jena-Stuttgart-Lübeck-Ulm, pp 1-548

Komárek J, Komárkova J (2003) Phenotype diversity of the cyanoprokaryotic genus Cylindrospermopsis (Nostocales); review 2002 (Přehled (fenotypová diversita) cyanoprokaryotního rodu Cylindrospermopsis (Nostocales). Czech Phycology 3:130

Komárek J, Komárkova J (2004) Taxonomic review of the cyanoprokaryotic genera Planktothrix and Planktothricoides [Taxonomický přehled rodů Planktothrix a Planktothricoides (Cyanoprokaryota)]. Czech Phycology 4:1-18

Komárek J, Anagnostidis K (2005) Cyanoprocaryota. Teil: Oscillatoriales. In: Büdel B, Krienitz L, Gärtner G, Schagerl M (eds) Süßwasserflora von Mitteleuropa 19/2. Elsevier GmbH, München, pp 1-759

Komárek J, Komárkova J (2006) Diversity of Aphanizomenon-like cyanobacteria (Diverzita sinic z okruhu rodu Aphanizomenon). Czech Phycology 6:1-32

Komárek J, Zapomělová E (2007) Planktic morphospecies of the cyanobacterial genus Anabaena $=$ subg. Dolichospermum-1. Part: coiled types. Fottea 7:1-31

Komárek J, Zapomělová E (2008) Planktic morphospecies of the cyanobacterial genus Anabaena=subg. Dolichospermum-2. Part: straight types. Fottea 8:1-14

Komárek J (2010) Modern taxonomic revision of planktonic nostocacean cyanobacteria: a short review of genera. Hydrobiologia 639:231-243

Li R, Carmichael WW, Brittain JE, Eaglesham GK, Shaw GR, Mahakhant A, Noparatnaraporn N, Yongmanitchai W, Kaya K, Watanabe MM (2001a) Isolation and identification of the cyanotoxin cylindrospermopsin and deoxycylindrospermopsin from a Thailand strain of Cylindrospermopsis raciborskii (Cyanobacteria). Toxicon 39:973-980

Li R, Carmichael WW, Brittain S, Eaglesham G, Shaw G, Liu Y, Watanabe M (2001b) First report of the cyanotoxins cylindrospermopsin and 
dexycylindrospermopsin from Raphidiopsis curvata (Cyanobacteria). J Phycol 37:1121-1126

Mankiewicz-Boczek J, Kokociński M, Gagała I, Pawełczyk J, Jurczak T, Dziadek J (2012) Preliminary molecular identification of cylindrospermopsin-producing Cyanobacteria in two Polish lakes (Central Europe). FEMS Microbiol Lett 326:173-179

Mc Gregor GB, Sendall BC, Hunt LT, Eaglesham GK (2011) Report of the cyanotoxins cylindrospermopsin and deoxy-cylindrospermopsin from Raphidiopsis mediterranea Skuja (Cyanobacteria/Nostocales). Harmful Algae 10:402-410

Messineo V, Bogialli S, Melchiorre S, Sechi N, Lugliè A, Casiddu P, Mariani MA, Padedda BM, Di Corcia A et al (2009) Cyanobacterial toxins in Italian freshwaters. Limnologica 39:95-106

Messineo V, Melchiorre S, Di Corcia A, Gallo P, Bruno M (2010) Seasonal succession of Cylindrospermopsis raciborskii and Aphanizomenon ovalisporum blooms with cylindrospermopsin occurrence in the volcanic Lake Albano, Central Italy. Environ Toxicol 25:18-27

Metcalf JS, Barakate A, Codd GA (2004) Inhibition of plant protein synthesis by the cyanobacterial hepatotoxin, cylindrospermopsin. FEMS Microbiol Lett 235:125-129

Mihali TK, Kellmann R, Muenchhoff J, Barrow KD, Neilan BA (2008) Characterization of the gene cluster responsible for cylindrospermopsin biosynthesis. Appl Environ Microbiol 74:716-722

Mikalsen B, Boison G, Skulberg OM, Fastner J, Davies W, Gabrielsen TM, Rudi K, Jakobsen KS (2003) Natural variation in the microcystin synthetase operon $m c y A B C$ and impact on microcystin production in Microcystis strains. J Bacteriol 185:2774-2785

Norris RL, Eaglesham G, Pierens G, Shaw G, Smith MJ, Chiswell RK, Seawright AA, Moore MR (1999) Deoxycylindrospermopsin, an analog of cylindrospermopsin from Cylindrospermopsis raciborskii. Environ Toxicol 14:163-165

Nurmi J, Wikman T, Karp M, Lövgren T (2002) High-performance real-time quantitative RT-PCR using lanthanide probes and a dual-temperature hybridization assay. Anal Chem 74:3525-3532

Ohtani I, Moore RE, Runnegar MTC (1992) Cylindrospermopsin: a potent hepatotoxin from the blue-green alga Cylindrospermopsis raciborskii. J Am Chem Soc 114:7941-7942

Orr PT, Rasmussen JP, Burford MA, Eaglesham GK, Lennox SM (2010) Evaluation of quantitative real-time PCR to characterize spatial and temporal variations in cyanobacteria, Cylindrospermopsis raciborskii (Woloszynska) Seenaya et Subba Raju and cylindrospermopsin concentrations in three subtropical Australian reservoirs. Harmful Algae 9:243-254

PN-ISO 7150-1 (2002) Determination of ammonia nitrogen. The manual spectrometric method. International Organization for Standardization. www.iso.org

PN-73/C-04576/14 (1973) Water and wastewater. Calculation of total nitrogen. International Organization for Standardization. www.iso.org

Preußel K, Stüken A, Wiedner C, Chorus I, Fastner J (2006) First report on cylindrospermopsin producing Aphanizomenon flosaquae (Cyanobacteria) isolated from two German lakes. Toxicon 47:156-162

Preußel K, Wessel G, Fastner J, Chorus I (2009) Response of cylindrospermopsin production and release in Aphanizomenon flosaquae (Cyanobacteria) to varying light and temperature conditions. Harmful Algae 8:645-650

Quesada A, Moreno E, Carrasco D, Paniagua T, Wörmer L, De Hoyos C, Sukenik A (2006) Toxicity of Aphanizomenon ovalisporum (Cyanobacteria) in Spanish water reservoir. Eur J Phycol 41:39-45

Rasmussen JP, Cursaro M, Froscio SM, Saint CP (2008) An examination of the antibiotic effects of cylindrospermopsin on common gram-positive and gram-negative bacteria and the protozoan Naegleria lovaniensis. Environ Toxicol 23:36-43
Rücker J, Stüken A, Nixdorf B, Fastner J, Chorus I, Wiedner C (2007) Concentrations of particulate and dissolved cylindrospermopsin in 21 Aphanizomenon-dominated temperate lakes. Toxicon 50:800-809

Saker ML, Griffiths DJ (2000) Effects of temperature on growth and cylindrospermopsin content of seven isolates of Cylindrospermopsis raciborskii (Nostocales, Cyanophyceae) from water bodies in northern Australia. Phycologia 39:349-354

Saker ML, Neilan BA (2001) Varied diazotrophies, morphologies and toxicities of genetically similar isolates of Cylindrospermopsis raciborskii (Nostocales, Cyanophyceae) from water bodies in northern Australia. Appl Environ Microbiol 99:749-757

Saker ML, Nogueira ICG, Vasconcelos VM, Neilan BA, Eaglesham GK, Pereira P (2003) First report and toxicological assessment of the cyanobacterium Cylindrospermopsis raciborskii from Portuguese freshwaters. Ecotoxicol Environ Saf 55:243-250

Schembri MA, Neilan BA, Saint CP (2001) Identification of genes implicated in toxin production in the cyanobacterium Cylindrospermopsis raciborskii. Environ Toxicol 16:413-421

Seifert M, McGregor G, Eaglesham G, Wickramsinghe W, Shaw G (2007) First evidence for the production of cylindrospermopsin and deoxy-cylindrospermopsin by the freshwater benthic cyanobacterium Lyngbya wollei (Farlow ex Gomont) Speziale and Dyck. Harmful Algae 6:73-80

Shaw GR, Sukenik A, Livne A, Chiswell RK, Smith MJ, Seawright AA, Norris RL, Eaglesham GK, Moore MR (1999) Blooms of cylindrospermopsin containing cyanobacterium Aphanizomenon ovalisporum (Forti), in newly constructed lakes, Queensland, Australia. Environ Toxicol 14:167-177

Shen X, Lam PKS, Shaw GR, Wickramasinghe W (2002) Genotoxicity investigation of a cyanobacterial toxin, cylindrospermopsin. Toxicon 40:1499-1501

Sivonen K, Jones G (1999) Cyanobacterial toxins. In: Chorus I, Bartram J (eds) Toxic cyanobacteria in water, a guide to their public health consequences, monitoring and management. $\mathrm{E}$ and FN Spoon, London, pp 41-111

Spoof L, Berg KA, Rapala J, Lahti K, Lepistö L, Metcalf JS, Codd GA, Meriluoto J (2006) First observation of cylindrospermopsin in Anabaena lapponica isolated from the boreal environment (Finland). Environ Toxicol 21:552-560

Starmach K (1989) Plankton roślinny wód słodkich. Państwowe Wydawnictwo Naukowe, Warszawa-Kraków, pp 1-496

Stüken A, Jakobsen KS (2010) The cylindrospermopsin gene cluster of Aphanizomenon sp. strain 10E6: organization and recombination. Microbiology 156:2438-2451

Svrcek C, Smith DW (2004) Cyanobacteria toxins and the current state of knowledge on water treatment options, a review. J Environ Eng Sci 3:155-185

Terao K, Ohmori S, Igarashi K, Ohtani I, Watanabe MF, Harada KI, Ito E, Watanabe M (1994) Electron microscopic studies on experimental poisoning in mice induced by cylindrospermopsin isolated from blue-green alga Umezakia natans. Toxicon 32:833-843

Törökné A, Asztalos M, Bánkiné M, Bickel H, Borbély G, Carmeli S, Codd GA, Fastner J, Huang Q, Humpage A, Metcalf JS, Rábai E, Sukenik A, Surányi G, Vasas G, Weiszfeiler V (2004) Interlaboratory comparison trial on cylindrospermopsin measurement. Anal Biochem 332:280-284

Wetzel RG, Likens GE (2000) Limnological analyses, 3rd edn. Springer, New York

White SH, Duivenvoorden LJ, Fabbro LD, Eaglesham GK (2006) Influence of intracellular toxin concentration on cylindrospermopsin bioaccumulation in freshwater gastropod (Melanoides tuberculata). Toxicon 47:497-509 
Wiedner C, Rücker J, Fastner J, Chorus I, Nixdorf B (2008) Seasonal dynamics of cylindrospermopsin and cyanobacteria in two German Lakes. Toxicon 52:677-786

Wood SA, Stirling DJ (2003) First identification of the cylindrospermopsinproducing cyanobacterium Cylindrospermopsis raciborskii in New Zealand. NZJ Mar Freshwater Res 37:821-828

Yilmaz M, Philips EJ, Szabo NJ, Badylak S (2008) A comparative study of Florida strains of Cylindrospermopsis and Aphanizomenon for cylindrospermopsin production. Toxicon 51:130-139
Zarenezhad S, Sano T, Watanabe MM, Kawachi M (2012) Evidence of the existence of toxic form of Cylindrospermopsis raciborskii (Nostocales, Cyanobacteria) in Japan. Phycol Res 60:98-104

Žegura B, Gajski G, Štraser A, Garaj-Vrhovac V (2011) Cylindrospermopsin induced DNA damage and alteration in the expression of genes involved in the response to DNA damage, apoptosis and oxidative stress. Toxicon 58:471-479

Zhang Z, Schwartz S, Wagner L, Miller W (2000) A greedy algorithm for aligning DNA sequences. J Comput Biol 7:203-214 